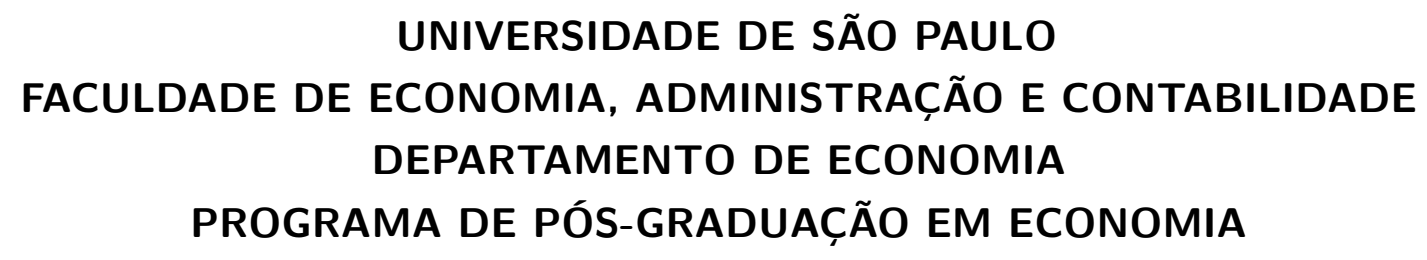

Effects on Fertility of The Brazilian Cash Transfer Program: Evidence from a Regression Discontinuity Approach

Efeitos do Programa Brasileiro de Transferência de Renda sobre A Fecundidade: Evidências Através do Uso de Regressão Descontínua

Luiz Henrique Ferreira Cruz e Superti

Orientador(a): Prof ${ }^{a}$. Dr ${ }^{a}$. Renata Del Tedesco Narita

São Paulo - Brasil

2018 
LUIZ HENRIQUE FERREIRA CRUZ E

SUPERTI

\section{Effects on Fertility of The Brazilian Cash Transfer Program: Evidence from a Regression Discontinuity Approach}

Efeitos do Programa Brasileiro de Transferencia de Renda sobre A Fecundidade: Evidencias Atraves do Uso de Regressao Descontfnua

Dissertacao apresentada ao Departamento de Economia da Faculdade de Economia, Administracao e Contabilidade da Universidade de Sao Paulo como requisito parcial para a obtencao do titulo de Mestre em Ciencias.

Orientador(a): Prof ${ }^{a}$. Dr ${ }^{\mathrm{a}}$. Renata Del Tedesco Narita

Versão Corrigida

Sao Paulo - Brasil

2018 
FICHA CATALOGRAFICA

Elaborada por Rafael Mielli Rodrigues - CRB-8/7286

Secao de Processamento Tscnico do SBD/FEA/USP

Superti, Luiz Henrique Ferreira Cruz e

Effects on fertility of the Brazilian cash transfer program: evidence from a regression discontinuity approach / Luiz Henrique Ferreira Cruz e

Superti. - Sao Paulo, 2018

$73 \mathrm{p}$.

Dissertacao (Mestrado) - Universidade de Sao Paulo, 2018

Orientador: Renata Del Tedesco Narita.

1. Politicas publicas 2. Fecundidade 3. Programa Bolsa Familia 4. Econometria I. Universidade de Sao Paulo. Faculdade de Economia, Administracao e Contabilidade. II. Titulo.

CDD - 320.6 
Prof. Dr. Vahan Agopyan

Reitor da Universidade de São Paulo

Prof. Dr. Adalberto Américo Fischmann

Diretor da Faculdade de Economia, Administração e Contabilidade

Prof. Dr. Hélio Nogueira da Cruz

Chefe do Departamento de Economia

Prof. Dr. Ariaster Baumgratz Chimeli

Coordenador do Programa de Pós-Graduação em Economia 


\section{Acknowledgements}

I appreciate all the support given by my family; the help and happiness of my graduate colleagues, who made the graduate studies easier and more fun. Special thanks to Raphael Corbi, François Gerard, Sergio Gorodski Mondrzejewski, Joana Naritomi and Agnieszka Rec for thoughtful comments on my ideas and writing. 

"A espécie humana [...] está destinada a esperar infinitamente os efeitos e a buscar infinitamente as causas, pelo menos é o que, até hoje, infinitamente tem feito." (José Saramago, História do Cerco de Lisboa, Capítulo 7) 



\section{Abstract}

The Brazilian cash transfer program Bolsa Familia is a very, if not the most, important pillar of Brazil's welfare system. However, there is a common sense that the program's transfers incentive beneficiary couples to have more children. Using federal data (Cadúnico and Caixa databases) and the eligibility rules for the program, I propose a quasi-experimental approach to verify both unconditional (UCT) and conditional transfers (CCT) on the beneficiaries' fertility rates between 2011 and 2015, through a fuzzy regression discontinuity approach. Measure problems associated with the data (e.g.: manipulation, heaping, attriton), are solved using a non parametric estimation proposed by Gerard, Rokkanen \& Rothe (2016), which determines lower and upper bounds for treatment effects. On one hand, there is no evidence that the CCT component affects the beneficiaries' fertility rates, but on another, the more flexible component of Bolsa Família, UCT, possibly reduced the fertility rates for the most poor. Those results are counter intuitive with the theoretical literature so far, but in line with the majority of other studies analyzing similar transfer programs in Latin America.

Key-words: Cash Transfers. Bolsa Família. Fertility. Regression Descontinuity. 



\section{Resumo}

O programa de transferência de renda Bolsa Família é um importante pilar da seguridade social brasileira, mas há um senso comum de que as transferencias do programa incentivam casais beneficiários a terem mais filhos. Utilizando base de dados do governo federal (Cadúnico e Caixa) e valendo-se dos critérios de eligibilidade, propõe-se uma inédita análise quase experimental para estudar os efeitos das transferências não condicionais (UCT) e das condicionais (CCT) sobre a fecundidade das beneficiárias entre os anos de 2011 a 2015, através de uma regressão descontínua fuzzy. Problemas de medida associados à base (e.g.: manipulação, arredondamento, atrito) são remediados com a estimação não paramétrica proposta por Gerard, Rokkanen \& Rothe (2016), em que se determina limites superiores e inferiores aos efeitos de tratamento. Por um lado, não há evidência de que o componente CCT afete a fecundidade das beneficiárias, mas por outro, o componente mais flexivel do Bolsa Família, o UCT, possivelmente reduziu a fecundidade das beneficiárias mais pobres, sobretudo no Nordeste. Tais resultados são contraintuitivos em relação à literatura teórica até então, mas em linha com a grande maioria dos resultados encontrados em programas similares da América Latina.

Palavras-chave: Bolsa Família. Fecundidade. Regressão Descontínua. Transferência de renda. 



\section{List of Figures}

Figure 1 - Proportion of Family Income Reports . . . . . . . . . . . . . . . . . 31

Figure 2 - RD Empirical Approach Summary: Sample and Measurement concerns at each cutoff . . . . . . . . . . . . . . . . . . . . 33

Figure 3 - The effect of per capita income on the Prob. of: . . . . . . . . . . . . 37

Figure 4 - Probability of having an additional child - 2012 to 2015 . . . . . . . . . 40

Figure 5 - The effect of per capita income on the Prob. of being: . . . . . . . . . . 41

Figure 6 - Probability of having an additional child - 2012 to 2015 . . . . . . . . . 43

Figure 7 - 2015 Update Pattern around the $\mathrm{R} \$ 140$ cutoff . . . . . . . . . . . . . . 44

Figure 8 - McCrary Test for UCT cutoff: extreme poverty line* . . . . . . . . . 65

Figure 9 - McCrary Test for CCT cutoff: poverty line, non-heaped* . . . . . . . . 65

Figure 10 - McCrary Test for CCT cutoff: poverty line, non-heaped* . . . . . . . . 66

Figure 11 - McCrary Test for update pattern around the R $\$ 140$ cutoff* $^{*}$. . . . . . 66 



\section{List of Tables}

Table 1 - Eligibility criteria and benefits values of BF (In Brazilian Reais - R $\$$ ) . . 26

Table 2 - Effect of having a 2011 per capita income below the extreme poverty cutoff $(\mathrm{R} \$ 70)$ on the Prob. of earning UCT, conditional on being a BF beneficiary (2011 allocation). Dependent variable: UCT beneficiary $(=1 / 0) 38$

Table 3 - Average treatment effects of Bolsa Família UCT on the probability of having a birth, from 2012 to 2015 (dependent dummy variable) . . . . . 39

Table 4 - Effect of having a 2011 per capita income below the poverty cutoff ( $\mathrm{R} \$ 140)$ on the Prob. of earning CCT and UCT. Dependent variable: CCT/UCT beneficiary $(=1 / 0) \ldots \ldots . \ldots . \ldots . \ldots 42$

Table 5 - Average treatment effects of Bolsa Familia CCT on the probability of having a childbirth, from 2012 to 2015. Dependent Variable: dummy variable indicating at least one childbirth for the 2012-2015 period . . . 43

Table 6 - Effect of having a 2011 per capita income below the poverty cutoff ( $\mathrm{R} \$ 70)$ on the Prob. of having an up-to-date Cadúnico registry in 2015. Dependent variable: Up-to-date 2015 Cadúnico Registry $(=1 / 0)$. . . . . 44

Table 7 - Average treatment effects of Bolsa Familia CCT on the probabilty of having a childbirth, from 2012 to 2015 . . . . . . . . . . . . . 46

Table A1 - Cadúnico's Federal programs . . . . . . . . . . . . . . . . . 55

Table A2-Summary Statistics (2011) . . . . . . . . . . . . . . 55

Table A3 - Difference-in-Difference estimates for Update in Cadúnico Variables Gamma coefficients . . . . . . . . . . . . . . . . 57

Table A4 - Difference-in-Difference estimates for Update in Cadúnico Variables Beta coefficients . . . . . . . . . . . . . . . 5 58

Table A5 - Covariates Comparison - Above and Below the poverty cutoff . . . . . . 59

Table A6 - Average treatment effects of Bolsa Família UCT on the probability of having a childbirth, from 2012 to 2015: By Brazilian Federal Regions . . 61

Table A7 - Average treatment effects of Bolsa Familia UCT on the probabilty of having a childbirth, from 2012 to 2015: By Age Groups and Groups of Low Parity . . . . . . . . . . . . . . . . . . . 62

Table A8 - Average treatment effects of Bolsa Familia CCT on the probability of having a childbirth, from 2012 to 2015: By Brazilian Federal Regions . .

Table A9 - Average treatment effects of Bolsa Familia CCT on the probabilty of having a childbirth, from 2012 to 2015: By Age Groups and Groups of Low Parity . . . . . . . . . . . . . . . . . 64 



\section{List of abbreviations and acronyms}

BF Bolsa Família

CCT Conditional Cash Transfer

UCT Unconditional Cash Transfer 



\section{Contents}

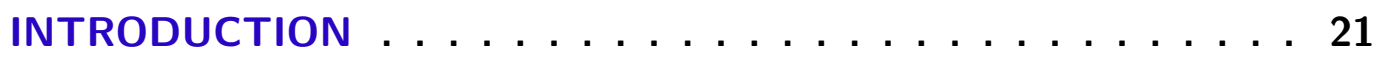

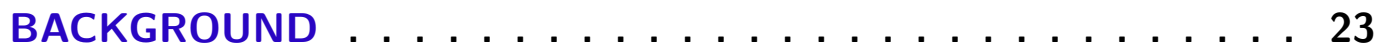

2.1 Cash transfers: Conditional or Unconditional? . . . . . . . . . 23

2.2 Cash Transfers and effects on Fertility . . . . . . . . . . 24

2.3 The Brazilian Program Bolsa Família . . . . . . . . . . . . . 25

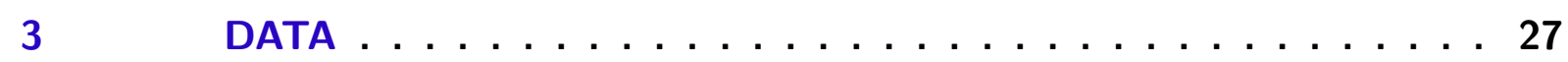

$3.1 \quad$ BF Registration and database construction . . . . . . . . 27

3.2 Database . . . . . . . . . . . . . . . . . . . . . . 28

3.3 Measurement Concerns: Update pattern in Cadúnico . . . . . . . 29

3.4 Measurement Concerns: Heaping . . . . . . . . . . . . 30

3.5 Measurement Concerns: Manipulation . . . . . . . . . . 32

3.6 Measurement Concerns: Solution approach . . . . . . . . . . 32

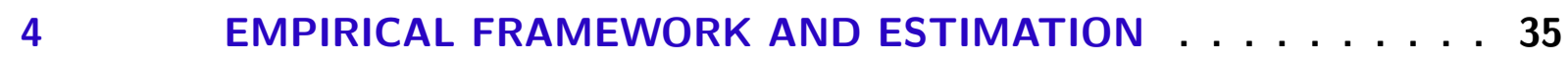

$4.1 \quad$ Unconditional Cash Transfer . . . . . . . . . . . . . . 35

$4.2 \quad$ Conditional Cash Transfer . . . . . . . . . . . . . . . . 40

$4.3 \quad$ Heterogeneity Exercises . . . . . . . . . . . . . . . . . 45

Conclusion $\ldots \ldots \ldots \ldots \ldots \ldots \ldots \ldots$

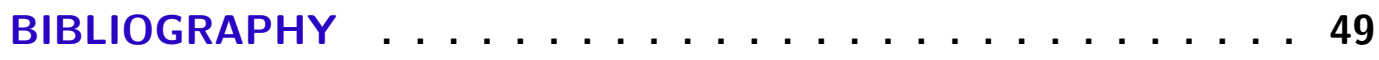

$\begin{array}{ll}\text { APPENDIX } & 53\end{array}$

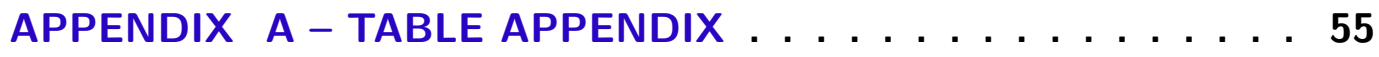

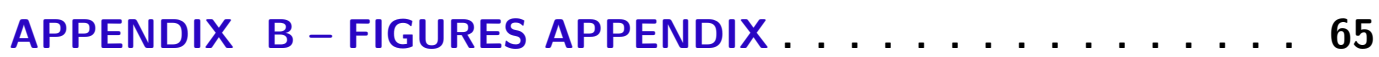





\section{Introduction}

Since the pioneering experiment of Progresa in Mexico in the late 1990s, cash transfers programs are extensively used in the developing world, especially in Latin America, as a way to improve human capital accumulation and to break the intergenerational cycle of poverty (PELLEGRINA, 2012). Past literature shows that, in general, those programs have improved educational and health outcomes, long-term human capital accumulation, and have promoted short-term reduction in poverty (see Fiszbein, Schady \& Ferreira (2009) and Lagarde, Haines \& Palmer (2007) for a review). Those programs, however, can have indirect effects on other factors, such as fertility decisions. The theoretical literature suggests a substitute relation between quantity and quality of children in fertility decisions (STECKLOV et al., 2006; SCHULTZ, 1997; BECKER; LEWIS, 1974; COCHRANE, 1975). Cash transfers programs can affect those decisions in two main ways, depending on the Cash transfer design. Conditional Cash transfer programs (CCTs) condition the transfer through school attendance and medical visits, they affect the price of child "quality", usually measured as educational and health outcomes (price effect). Unconditional Cash Transfer (UCT), as the name suggests, does not have any kind of conditional attached to the grant, but can still affect fertility decisions through an income effect. I investigate whether the Brazilian Cash Transfer Program Bolsa Família (BF), through its two conditional and unconditional components, encouraged beneficiary women to have children during the 2011-2016 period. My research evaluate exogenous variation in fertility using the eligibility rule used by the Brazilian government to authorize BF's payments. However, as most of the data is self-reported and, furthermore, is not updated on a yearly basis, it suffers from heaping, attrition and manipulation. Standard average treatment effects are possible to estimate using families who do not heap their income and, using a non-parametric approach suggested by Gerard, Rokkanen \& Rothe (2016), it is possible to identify bounds on the treatment effects when manipulation is present. No evidence of price effect was found in this study, but persistent evidence of negative effects, through bounds and point estimates, were present for the UCT component. While some studies analyzed CCT or UCT effects on fertility, this study is the first to investigate both effects for the same cohort, and the first to analyze BF effects using a quasi experimental approach. Additionally, provided that around 40 million of Brazilians are covered by BF, the results are relevant for policy and demographic debates. This study is divided as follows: Section 2 discusses the economic theory behind cash transfers and fertility and gives a background on the Bolsa Familia. Section 3 describes the data, while Section 4 provides the Empirical Framework and Results. Finally, Section 5 concludes. 



\section{Background}

\subsection{Cash transfers: Conditional or Unconditional?}

CCTs and UCTs distribute cash to poor households as a way to redistribute income and break the cycle of poverty. The main difference is that UCTs give cash with no strings attached, while CCTs programs usually transfer cash contingent on certain behaviors that improve the household's human capital accumulation. While UCTs act solely through an income effect, CCTs alter the income and relative price of schooling and health services, having thus a price effect. (STECKLOV et al., 2006; BAIRD et al., 2013).

CCTs have two main justifications for attaching conditions (FISZBEIN; SCHADY; FERREIRA, 2009; BAIRD et al., 2013): First, private investment in human capital among the poor is suboptimal from a social point of view, as for example, where there are market failures. These kind of failures can arise from asymmetric information (e.g., parents do not know the value of schooling) or differences in discount rates between parents and children. However, even if privately optimal, these choices could be below the social optimal. Second, when payments are only socially acceptable through some sort of condition. Particularly, it could be the case that the electorate has certain views on distributive justice: that is, believing that it is better to meet conditions rather than simply receive money "for free".

Different from CCTs, UCTs are justified under the pretext that the cause for suboptimal education and health choices is income. If, giving sufficient income, the household's behavior is already optimal, both socially and privately, attaching a condition to the cash transfer could cause distortions that move their decisions away from the optimal. By attaching a condition, a cash transfer may exclude segments of the population who do cannot comply with program rules and may equally be in need of cash transfers (BAIRD et al., 2013)

While UCTs cover a wider range of programs, such as pension schemes, disability benefits and income support, studies shows that both CCTs and UCTs are efficient in improving educational (e.g.: attendance, enrollment rates) and health outcomes (e.g.: nutrition, frequency of attending doctors)(FISZBEIN; SCHADY; FERREIRA, 2009; LAGARDE; HAINES; PALMER, 2007; BAIRD et al., 2013). However, CCTs generally are more effective at improving schooling outcomes, while UCTs are comparatively better for other outcomes: in Malawi, for instance, UCTs were more effective in preventing teen pregnancies(BAIRD; MCINTOSH; ÖZLER, 2011; BAIRD et al., 2013). It is important to note that although UCT and CCT appear to be distinct programs, they can be combined in a range of ways that can include elements from both types of transfers. Bolsa 
Familia is a good example: although it sets conditions on all beneficiaries, there is an UCT component for the very poor.

\subsection{Cash Transfers and effects on Fertility}

A cash transfer alleviates income restraints, allowing parents to improve their children's education and consume more health services. That is, it not only allows parents to improve the "quality" of each child, but also creates better conditions for having another child. In the case of a CCT, the amount transferred is usually a function of the number of children in a family, in which not yet born children can be perceived as an additional source of income. A common concern is then that cash transfers could increase fertility.

CCTs' conditions, however, are imposed to reduce the price of children's "quality" (STECKLOV et al., 2006). In the Becker and Lewis fertility static model (BECKER; LEWIS, 1974), where parents choose both quantity and quality of children but there's a substitution relation between them, a CCT have an ambiguous effect fertility (STECKLOV et al., 2006; SCHULTZ, 1997). On the other hand, an UCT affects fertility only through an income channel. In the Becker and Lewis model, this effect is negative* (STECKLOV et al., 2006).

Evidence from reduced-form studies suggests that CCTs' ambiguous impact on fertility could depend on the emphasis each program puts in quantity and quality costs, but also on parent's preference. In Progresa, as a way of discouraging fertility, parents would only receive child-related benefits if their sons and daughters were at least six years old. On the one hand, no effect was encountered in Mexico, Nicaragua, or South Africa, whether measured by reduced-form regressions or survival analysis (STECKLOV et al., 2006; SCHULTZ, 2004; TODD; WINTERS; STECKLOV, 2012; TODD; WOLPIN, 2006; BOR, 2013). On the other hand, a positive effect were encountered on Honduras. On the other countries, transfers were constant established amounts, and any additional children would not be included as beneficiaries. In Honduras, however, the transfers provided a fixed amount per child, and without a limit on the number of eligible children ${ }^{\dagger}$. But In South Africa the CCT actually reduced beneficiaries teenagers' pregnancy rate (BOR, 2013), and in the Argentinian CCT, with more flexible conditions such as no limit rule, Garganta et al. (2014) found a positive effect only for first parity beneficiaries.

Bolsa Familia was not implemented as part of a randomized experiment and until recently no direct information of beneficiaries was available. To counter the no availability,

*provided that cash transfers have effects on permanent income and the costs for the households to fulfill CCT's requirements are small

${ }^{\dagger}$ Given that the period of analysis was just 2 years, another factor that could explain the effect is that beneficiaries are actually advancing fertility decisions rather than altering their optimal number of children 
Signorini, Queiroz et al. (2011), Rocha (2010) and Simões \& Soares (2012) inferred effects by using cross-sectional data provided by the census or federal non-BF related agencies. Their results verified that the BF program, like Progresa and RPS, did not encourage fertility ${ }^{\ddagger}$.

Reduced-form evidence, however, can mistakenly accuse an effect on fertility if families are actually reducing time between births (TODD; WINTERS; STECKLOV, 2012). This could also happen for a non-eligible household: It can advance an already planned pregnancy, expecting to become eligible to reduce future child rearing costs. For long term effects, the dynamic behavioral model of parental decisions about fertility and schooling proposed by Todd and Wolpin seems appropriate ${ }^{\S}$. In their analysis, a CCT does not have effects on fertility, and a cash-equivalent UCT has little effect on a couple's fertility decisions.

\subsection{The Brazilian Program Bolsa Família}

The Brazilian Cash Transfer Program, Bolsa Familia, was created in 2003, merging 4 earlier smaller-scale, poverty-alleviating programs. Within three years, BF covered around eleven million families, becoming the largest CCT program in the world at that time. In 2009, the program was authorized to expand to around 12.4 million families (SOARES et al., 2010; LINDERT et al., 2007).

For a family to be eligible, it must have a per capita income below a certain cutoff, which changed year by year, as shown in 1 . As beneficiaries, they can receive a basic grant, and variable grants, which depends on the number of children and their age. Eligibility for each type of grant is divided into two categories based on income: extreme poverty and poverty. Only those in the first category receives the basic amount. Unlike most variable benefits, which are linked to some conditionality, the basic amount is unconditional.

Until 2011, a family could receive three variable benefits; this was subsequently increased to five. For 2015, the variable benefits fell into three categories: pregnant, nursing, and 0-15 years. The pregnancy benefit, implemented in 2011, is given to families with pregnant women aged 14 to 44 years. The nursing benefit, also implemented in 2011, is given to families with toddlers from 0 to 6 months of age, with each child earning one benefit. Finally, the 0 to 15 benefit is given to families with children under the age of fifteen; again, one benefit per child Bolsa Família also provides a benefit for older teenagers (BVJ), instituted in 2007, but this is not a variable benefit. Families with teenagers ages

\footnotetext{
†Parents’ preference play an important role in fertility decisions. As Morgan \& King (2001) point out, couples may desire children differently across parities; for instance, a first child may be desired because of social coercion or biological predisposition, whereas a second child might be wanted because parents desire a couple as offspring.

$\S$ One could also use right-censoring models, as in Todd, Winters \& Stecklov (2012) or Bor (2013), or analyzing larger periods
} 
15-17 years are eligible for at most 2 BVJs. In 2012, the government also added a benefit to overcome poverty (BSP), given to families who fall into the extreme poverty category. This benefit gives the necessary amount to the family to have at least an income per capita above the extreme poverty line. 1 also shows the evolution of the benefit values.

Table 1 - Eligibility criteria and benefits values of BF (In Brazilian Reais - R $\$$ )

\begin{tabular}{|c|c|c|c|c|c|c|c|c|c|c|}
\hline \multicolumn{3}{|c|}{ Criteria } & 2003-05 & 2006 & 2007 & 2008 & $2009 / 10$ & 2011 & 2012-13 & 2014-15 \\
\hline \multirow{2}{*}{\multicolumn{2}{|c|}{ Elegibility }} & Extreme Poverty & 50 & 60 & 60 & 60 & 70 & 70 & 70 & 77 \\
\hline & & Poverty & 100 & 120 & 120 & 120 & 140 & 140 & 140 & 154 \\
\hline \multirow{8}{*}{ Benefit } & Basic & \multirow{4}{*}{ Extreme Poverty } & 50 & 50 & 58 & 62 & 68 & 70 & 70 & 77 \\
\hline & Variable & & 15 & 15 & 18 & 20 & 22 & 32 & 32 & 35 \\
\hline & BVJ & & - & - & 30 & 30 & 33 & 38 & 38 & 42 \\
\hline & BSP & & - & - & - & - & - & - & Hiatus & Hiatus \\
\hline & Basic & \multirow{4}{*}{ Poverty } & - & - & - & - & - & - & - & - \\
\hline & Variable & & 15 & 15 & 18 & 20 & 22 & 32 & 32 & 35 \\
\hline & BVJ & & - & - & 30 & 30 & 33 & 38 & 38 & 42 \\
\hline & BSP & & - & - & - & - & - & - & - & - \\
\hline
\end{tabular}

CCT have a fixed number of installments, based on children's age, so beneficiary families keep receiving benefits even if they are no longer eligible through income. UCT payments does not have a which does not occur with UCT payments.

Conditionalities are defined by educational and health criteria. For health, children up to 7 years old are required to have up-to-date vaccinations, and pregnant women must have regular medical check-ups and prenatal examinations. Children and teenagers must be enrolled in school, and have a minimum attendance of $85 \%$ for those under 15 years old, and a minimum of $75 \%$ for those between 15 and 17. (MDS, BRAZILIAN MINISTRY FOR AGRARIAN AND SOCIAL DEVELOPMENT, 2015).

In summary, BF can have two effects on fertility. For those below the extreme poverty line, they earn both a UCT, which leads to a decrease in fertility (STECKLOV et al., 2006), and conditional payments, which have ambiguous effects, as discussed earlier. Those falling between poverty and extreme poverty only receive conditional payments. To verify the effects of the UCT and CCT components of BF, I use a regression discontinuity on each eligibility cutoff. Particularly, I will use the allocation of beneficiaries in 2011, and analyze the outcomes in 2015. The large window of 4 years reduces the confounding effect of birth spacing, since the average birth spacing of most Latin American countries is 28 to 36 months ((TODD; WINTERS; STECKLOV, 2012)). 


\section{Data}

\subsection{BF Registration and database construction}

Family eligibility is determined based on household registry data which are collected and transmitted into a central database maintained by the Ministry for Agrarian and Social Development (MDS). Data collection and entry is decentralized to the municipalities, and database consolidation and management is controlled by he federal bank Caixa, which is contracted by the MDS via a performance-based contract (LINDERT et al., 2007; MDS, BRAZILIAN MINISTRY FOR AGRARIAN AND SOCIAL DEVELOPMENT, 2015). Caixa, as operating agent, is responsible for the payments to the families. Finally, eligibility determination is centralized by MDS, which then establishes the monthly beneficiary payroll. Each municipality has an estimate of how many families in its territory should be eligible to become beneficiaries. Those estimates are calculated by the MDS, and are open to public (MDS, BRAZILIAN MINISTRY FOR AGRARIAN AND SOCIAL DEVELOPMENT, 2015). The entry order for the program is defined by:

- Priority families: Indigenous groups, families in child labor situation or in insalubriousworking conditions;

- Other families are ordered by per-capita income and number of children. That is, families with less per capita income and more children are more successful in becoming beneficiaries;

Families fill up a standard federal questionnaire, which includes information on household composition, income, and living conditions. Municipalities can conduct registration interviews provided that timing and location of registration points are communicated to the population, but families can freely register at a permanent site provided by the city hall (LINDERT et al., 2007; MDS, BRAZILIAN MINISTRY FOR AGRARIAN AND SOCIAL DEVELOPMENT, 2015). The data which contains those questionnaires is called Cadúnico, which is not only used by BF, but also by other social programs controlled by the government, whether at federal or local levels. A brief description of these programs are in table A1.

Municipalities have funding incentives from the federal government to keep information reliable and programs can cross-validate information with other government data, such as tax reports or formal labor and employment information. These cross-validation procedures does not only occur during BF allocation, but every other year to verify 
eligibility. These procedures however, have limited use since it's difficult to find these information of the most poor, which are the the target of these programs. For this study, it does appear that fraud or non-eligibility is a major concern. In 2016, the government reported that a large cross-validation process cancelled only $4 \%$ of the benefits, and $3 \%$ of beneficiaries were called to update their information.*

I used the Cadúnico database, with a second database with BF payments information, provided by Caixa, from 2011 to 2015. The Cadúnico one is only available for researchers upon request to the MDS, where the Caixa data is open to the public. Each person registered in the Cadúnico database, and thus in the Caixa data, come with a unique identifier, called NIS.

\subsection{Database}

The Cadúnico database contains annual information for each member of the family, from 2011 to 2015. These information includes date of birth, education, current and past education, race, income, income composition (e.g.: work, pension, unemployed benefits, donations), general expenses, physical disabilities, an indicative for the head of the family, and degree of kinship in relation to the head of the family (i.e., son, daughter, brother, father, etc). There are also household's information such as number of rooms, number of bedrooms, floor and wall material. Indicators of whether electricity, running water, sewer and thrash collecting are present, and how they are supplied. I construct a base with women of childbearing age (16-44 years old) as observations, registered as head of the family and with at least one born child. Around $93 \%$ of those who reports as head of the family; the fact that only women can be the recipient for most social programs can explain this high rate. For date of birth, I consider only the data available year of 2015, the last up-to-date information. The Cadúnico database does not provide information whether the family is a BF beneficiary. For infer whether or not a women is beneficiary, I use the Caixa database.

The Caixa database provides information on BF payment information. It includes the head of the family NIS, municipality and monthly payment. All benefits, basic and variables, are bound to the head of the family bank account. The match for the year of 2011 performs well: More than 99.5\% payments are identified. ${ }^{\dagger}$ I define as an UCT, CCT and BF beneficiary in a given year anyone who receive at least one payment in that year.

${ }^{*}$ This small rate in 2016 could be the result of previous similar processes. However, they were not widely reported whether by federal government or the media.

†One problem in subsequent years is the inclusion of BSP in 2012. Not identified payments could either be to error or could be a "hiatus" payment. I consider that not identified payments are "hiatus" payment. This is not a major problem for two reasons. First, if we believe that the Caixa maintained their level of reliable payment information, then payment identification has small measurement error. Two, the proportion of not identified payments are larger for the extremely poor, with per capita income close to zero, which are distant from the poverty lines used by my RD analysis 
Since individuals can register at the end of the year, I extend the allocation window of 2011 until April 2012 for individuals who registered between October and December 2011 $\ddagger$. Merging the two data sets gives us 600,402 observations. Table A2 provide summary statistics of selected variables for 2011 for the merged data.

\subsection{Measurement Concerns: Update pattern in Cadúnico}

A distinct characteristic of Cadúnico is that is not a survey. Families does not update their information constantly, but their registry should be up-to-date every 2 years. Every year, MDS and municipalities jointly summons registered families with more than 2 years without updated info to register again, through advertising campaigns and local interviews. This procedure does not exclude the family from the data: If a family cannot be located families to update their info, it remains on the data for at least more 2 years. Other forms to be excluded from the Cadúnico are death, refusal to update info, fraud in previous years, court decision or by family solicitation. Analyzing data yearly can be difficult. A family not updating in a given year should be not be seen as a common attrition problem, specially if it was updated a year ago. According to Cadúnico rules, they are still eligible for social programs and thus have few incentives to update their info yearly. Beneficiaries have a strong incentive: They must keep their information updated to remain eligible. Municipalities are encouraged to keep BF beneficiaries with updated info, since BF transfers to the city are related to the quality of the update pattern. More than $90 \%$ of BF observations are updated in 2014 and 2015, while less than half (46\%) of Non-beneficiaries have updated info. This could be to a variety of reasons, for instance, after failing to be part of the program, families decide to not keep the registry updated; or that municipalities have better financial incentives to update BF beneficiaries than to all Cadúnico individuals. If non beneficiaries do not update due to lack of monitoring, using only up-to-date info could underestimate our results: beneficiaries updates even when they are not having additional child, and non beneficiaries could be only updating when they do have a child. There's two approaches to reduce the bias. One, it is fair to use non updated info, specially in the case of additional child. Both beneficiaries and nonbeneficiaries have incentives to keep information about the number of children updated. But non beneficiaries might not update not because they are unable to, but because there's no new information available to update. That is, while beneficiaries must update to keep the benefits, non beneficiaries might not feel compelled to update in the case of non changing life events. Using only up-to-date info in the case of children might increase the bias. Secondly, as we will show in other sections, a non-parametric approach will be used also to solve the different update pattern of beneficiaries and non-beneficiaries. Similarly,

\footnotetext{
${ }_{\ddagger}^{\ddagger}$ The median gap between registry and receiving a payment for those in 2011 and 2012 is 4 months
} 
the same logic applies for UCT beneficiaries: they might update their info differently from other BF beneficiaries, fearing that they might lose the benefit.

\subsection{Measurement Concerns: Heaping}

Self-report information is subject to heaping, and heaped values have negative effects on the results of statistical analyses when they are not random (BARRECA; LINDO; WADDELL, 2016; ZINN; WÜRBACH, 2016). In a RD analysis, manipulation tests are important to validate the identification strategy, but those tests do not differentiate between heap and manipulation. When the cutoff is a point of heaping, as in our case, there is a strong possibility that these tests will accuse manipulation where there are none (BARRECA; LINDO; WADDELL, 2016).

As in Barreca, Lindo \& Waddell (2016), I identify most of the heaped values graphically. Figure 1 indicates possible heaping points for total family income. There is a strong preference for final digit zero. Additionally, many individuals may round their income to the minimal wage imposed by law. Thus, there are two types of heaping values: multiples of the Minimal Wage (MW) in 2011 ( $\mathrm{R} \$ 540$ until March, $\mathrm{R} \$ 545$ forth) and those in multiples of 10 . In our case, the 2011 cutoffs themselves are heaping values and, as will be shown in the next section, the McCrary manipulation test shows signs of strong manipulation, specially on the cutoff, which could be the case that individuals are rounding their income. Provided that basic assumptions for the RD identification strategy are met, we have consistent estimates for non heaping observations. Without these assumptions, we can can still use non parametric design proposed by Gerard, Rokkanen \& Rothe (2016), to partially identify causal effects with bounds, using all the sample. Using all the sample for this case not only make us infer causal effects for not only those that heap their income, but it yields more statistical power. Additionally, the non parametric approach addresses manipulation and heaping problems simultaneously. 


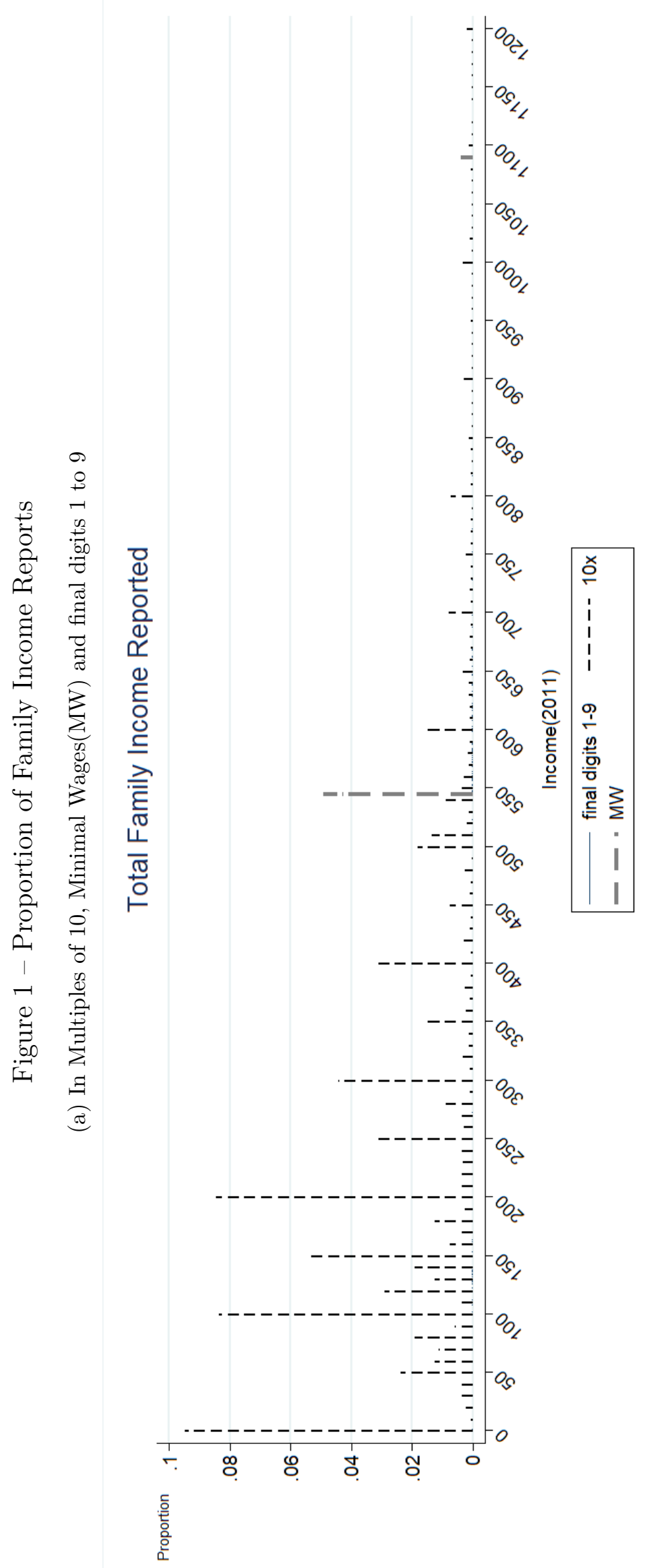




\subsection{Measurement Concerns: Manipulation}

I conduct manipulation tests using all the sample and the non-heaped subsample, to verify if there's manipulation of the running variable. More formally, I implement the test proposed by McCrary (2008), where we test for jumps in the density of per capita income in 2011, at the cutoffs. The test histograms for non-heaped subsample can be found in Figures 8 and 10 for the tests around the extreme poverty and poverty cutoffs, respectively. Using all the sample, we verify sign of manipulatio around both cutoffs ( $p$ valuesleq0.01). For the non-heaped samples, the standard McCrary test shows strong signs of manipulation around the $\mathrm{R} \$ 70$, while no evidence was found for non-heaped sample in $\mathrm{R} \$ 140$ cutoff (p-value $31 \%$ ). Manipulation is enough to invalidate the RD strategy, but with few additional hypotheses over the traditional ones in the RD analysis, Gerard, Rokkanen \& Rothe (2016) proposed the estimation of sharp bounds for the inference of causal effects. This strategy will be used when manipulation is present in the estimation.

\subsection{Measurement Concerns: Solution approach}

In short, with all the concerns involving the database (manipulation, heaping, attrition due to update), the following graph (2) presents a summary of the type of effect we are estimating in each cutoff, and the problems that each cutoff faces.

For the UCT cutoff, as seen before, we can have a problem of heaping, since the cutoff ends with a zero digit, which can make the manipulation test conclusions misleading. Eliminating non-heaped observations however, still showed signs of manipulation. Therefore, we will conduct the analyses with all the observations, heaped and non-heaped, and use the approach proposed by Gerard, Rokkanen \& Rothe (2016) which can be used to address the manipulation problems, and also any bias caused by differences in updated patterns by UCT and non UCT beneficiaries. This approach will be further developed in section 4 .

For the CCT cutoff, analyzing only non heaped observations takes the manipulation problem off. We could then, proceed with a RD strategy as normal. However, since we're comparing beneficiaries and non beneficiaries, we have an attrition problem among brought by the treatment. We briefly explored the ways to address this problem in other sections in a traditional RD context. Recapitulating, all families, beneficiaries and nonbeneficiaries, have incentives to inform they have an additional children, specially because the per capita income goes down, making them at least in better situation than before to be eligible. So for the case of offspring report, even when not updating the registry per se, we can consider that the registry has a valid information. This argument can be strengthen when we control by municipality, that is, when we are controlling for the closest infrastructure that each women has available to update the registry. In other words, 
Figure 2 - RD Empirical Approach Summary: Sample and Measurement concerns at each cutoff

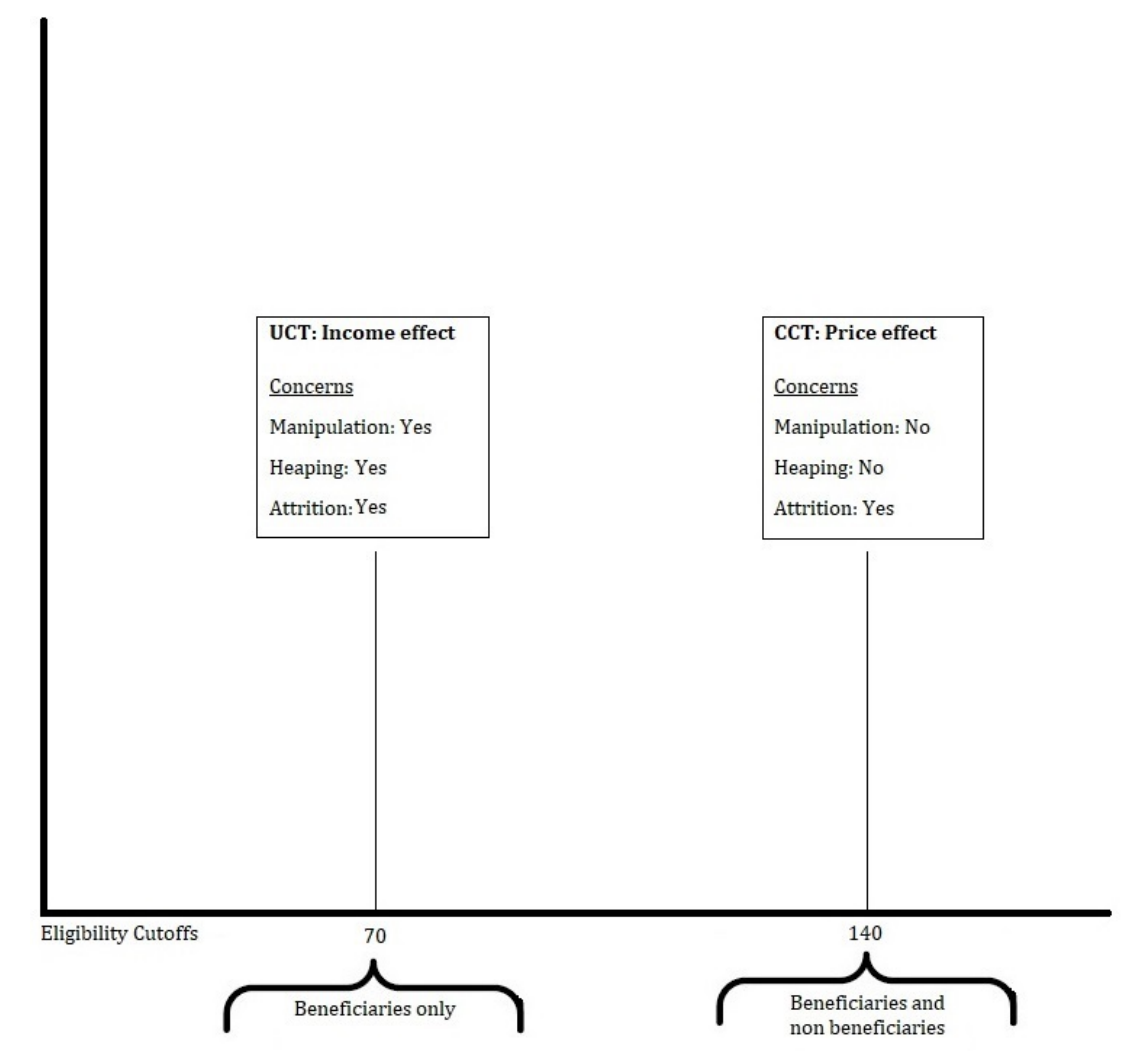

controlling for municipality roughly controls for update pattern. Hence we can obtain valid results with the standard RD analysis for non-heaped observations, for the CCT cutoff. For robustness, we will use the Gerard, Rokkanen \& Rothe (2016) approach to create bounds when the treatment causes attrition. This approach will be explained in the CCT section of the next chapter. 



\section{Empirical Framework and Estimation}

\subsection{Unconditional Cash Transfer}

In a traditional RD setup, our (local) average treatment effect (LATE) of interest is:

$$
\Theta=E\left(Y(1)-Y(0) \mid X=c, \lim _{x \rightarrow c_{1}^{-}} D(x)>\lim _{x \rightarrow c^{+}} D(x)\right)
$$

In which $\mathrm{D}$ denotes the treatment, assuming values 1 or 0 , as a function of the running variable, $\mathrm{X}$ ( per capita income in $\mathrm{R} \$ 2011$ values). $Y(1)$ and $Y(0)$ denote our outcome of interest, a dummy variable for at least one childbirth between 2012 and 2015, as a fuction of the treatment $\mathrm{UCT}$, and $c$ is our extreme poverty line of $\mathrm{R} \$ 70$.

As seen in the last section, however, the manipulation around the cutoff can result in sorting on unobservable characteristics around the cutoff and thus breaking RD standard identification assumptions. The same can be applied to those that should not be eligible but are due to heaping. Gerard, Rokkanen \& Rothe (2016) derives a non parametric methodology which is possible to identify sharp bounds on treatment effects under manipulation or other phenomenons that can alter the continuity around the cutoff, with only few additional hypotheses on the RD design. This approach relies on two types of unonbservable units, the always-assigned units, for which the realization of the running variable is always on one side of the cutoff (For our analysis, always assigned units can be any kind of unonbservable units on the left side of the cutoff that are different due to treatment. Those include manipulators, those that update more frequently, and non random heaping); and potentially assigned units. The additional hypotheses can be summarized as follows: The standard conditions for the RD identification are satisfied among potentially assigned, the manipulation is one-sided and that are no mass points of the running variable around the cutoff, that is, that those problematic units are not all concentrated in just one value. In our context, is not rational for someone to manipulate their income up, since all benefits are given below certain threshold. The non-intentional rounding may happen up, but for those just below the cutoff it does not matter, since they will still be at the cutoff. Secondly, is not difficult to believe that manipulators - or units that rounding their income - would concentrate their manipulated income in just one value. Under discontinuity of the running variable, the LATE could be any of the following two effects among compliers:

$$
\begin{aligned}
& \Theta_{+}=E\left(Y(1)-Y(0) \mid X=c^{+}, D^{-}>D^{+}\right) \text {or } \\
& \Theta_{-}=E\left(Y(1)-Y(0) \mid X=c^{-}, D^{-}>D^{+}\right)
\end{aligned}
$$

According to Gerard, Rokkanen \& Rothe (2016), $\Theta_{+}$is closer to $\Theta$ from a policy point of 
view, and it is the parameter of interest in this paper. Basically, we are estimating effects for those left of the cutoff. While we cannot observe or infer the type - always assigned or not - of any given unit, it is possible to estimate $\tau$, the proportion of always assigned, among those to the left of the cutoff. From known values of $\tau$ is then possible to estimate lower and upper bounds for the treatment effects (GERARD; ROKKANEN; ROTHE, 2016).

The first stage of an $\mathrm{RD}$ demonstrates that the condition $D^{-}>D^{+}$of 4.1 is respected. Figure 3 shows the discontinuity around the $\mathrm{R} \$ 70$ cutoff. Below the poverty line, the probability of being a BF beneficiary is high, with BF takeup of more than $80 \%$. Conditional on being beneficiary, we can see the large jump in UCT takeup in $3 \mathrm{~b}$ ). The graphical results are confirmed by regressions reported in table 2. Adding controls and income interactions actually increase the effect. It is worth noticing that our RD is not a sharp one, that is, one where the eligibility rule is strictly applied: that are some above the cutoff that earns the benefit, and some below that does not. Our RD strategy is then a fuzzy one, which we take that fact into account. The first stage for the CCT cutoff shows the same pattern. 


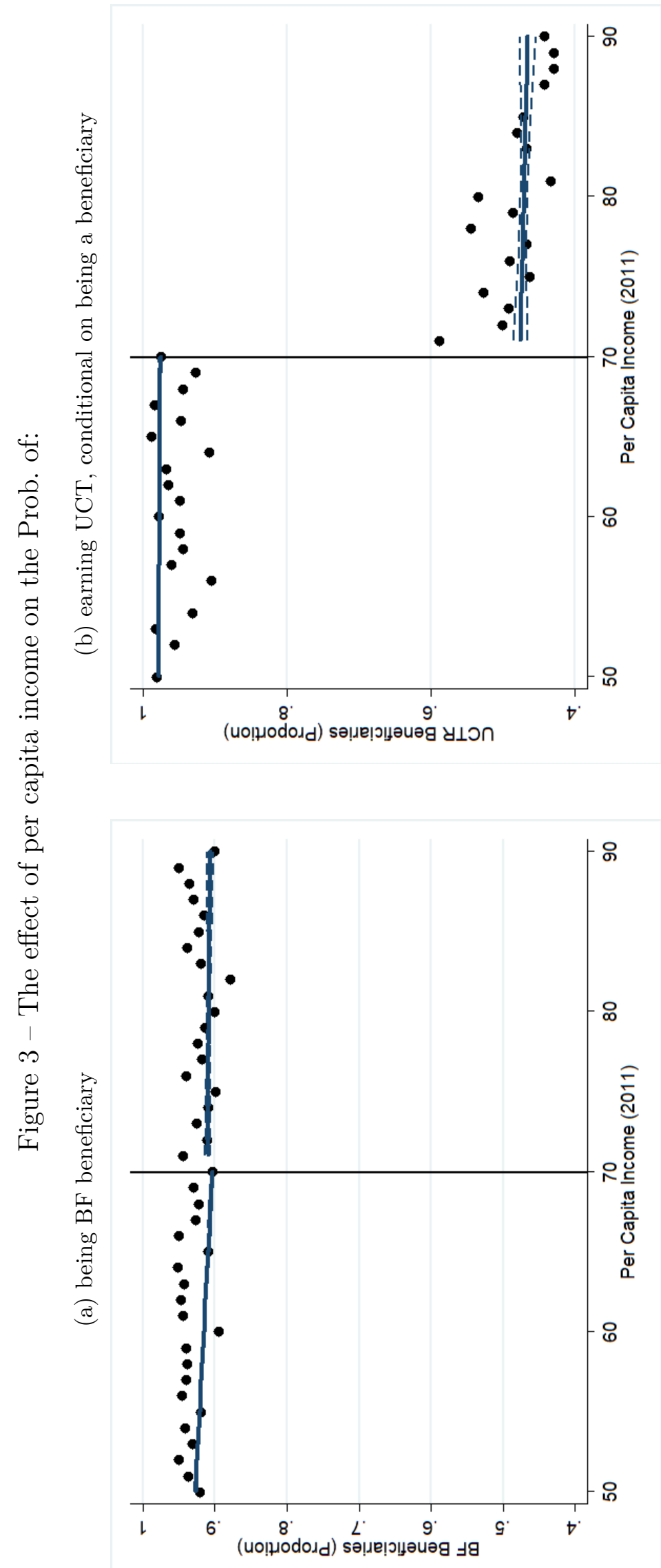


Table 2 - Effect of having a 2011 per capita income below the extreme poverty cutoff ( $\mathrm{R} \$ 70)$ on the Prob. of earning UCT, conditional on being a BF beneficiary (2011 allocation). Dependent variable: UCT beneficiary $(=1 / 0)$

\begin{tabular}{ccccc}
\hline \hline & \multicolumn{3}{c}{ Parametric Linear Regressions } \\
& $(1)$ & $(2)$ & $(3)$ & $(4)$ \\
\hline Below cutoff & $0.50^{* *}$ & $0.49^{* *}$ & $0.39^{* *}$ & $0.44^{* *}$ \\
& {$[2.54 \mathrm{e}-03]$} & {$[5.13 \mathrm{e}-03]$} & {$[7.10 \mathrm{e}-03]$} & {$[1.48 \mathrm{e}-02]$} \\
& & & & \\
Controls & No & No & Yes & Yes \\
Income Linear Interaction & No & Yes & Yes & Yes \\
Income Quadratic Interaction & No & No & No & Yes \\
\hline Observations & 168,686 & 168,686 & 79,033 & 79,033 \\
$R^{2}$ & 0.41 & 0.41 & 0.38 & 0.38 \\
\hline \hline
\end{tabular}

Notes: Regressions with BF beneficiaries (2011 allocation) women within 16 to 44 years of age and with at least one child. Regressions with municipality fixed effects. heterocedastic Robust-errors. Controls: Dummies for Race, Work, Education, Household (3 categories for number of rooms) Water, Wastewater, Garbage, Electricity, Income and Region categories of table A1. Dummies for age (5 years bin), disabilities, number of children and spouse. P-values: ${ }^{* *} \mathrm{p}<0.01,{ }^{*} \mathrm{p}<0.05$. Bandwidth calculated by Calonico, Cattaneo \& Titiunik (2014) methodology.

Difference in fertility around the cutoff in 2015 can be seen in graph 4 . Visually, it's possible to say that we have no differences on the fertility around the cutoff, that might be the result of the benefits. Results for average treatment effects* on fertility are displayed in table 3. It's very important to notice that the treatment effects here may be capturing an indirect effect of BF on the non-beneficiaries: They might increase their fertility to be part of the program. This could underestimate the results. We have little reason to believe it that the bias is large, since both treated and control groups had few births, and non-BF have already a lower fertility during the analyzed period. Panel Basic inputs of table 3 reports inputs for our bounds design. Note that $\tau$ estimate is not very high, but still demonstrates evidence of manipulation. The treatment take-up at the cutoff estimated by a local linear regression is at $50 \%$, in line with parametric estimations of 2 . A low $\tau$ - increase in take-up relation tights the bounds, making our inference more reliable (GERARD; ROKKANEN; ROTHE, 2016). The 2nd stage results can be found in panels $\mathrm{B}$ and $\mathrm{C}$. Ignoring manipulation shows that we cannot reject that the UCT program has no effect on the birth rate during the period: The point estimate is very close to zero. Surprisingly, UCT beneficiaries had more births in relative terms (panel A). The bounds around the point estimation are very asymmetric. The lower bound give us a -12 p.p. on

*It's important to notice that, since BF is allocated on a monthly basis, dynamics in treatment assignment are present. The bounds calculated here represents a dynamic Intent-to-treat (ITT) effect, where we verify the effect of UCT in fertility rates without controlling the families - or the government behavior after 2011 allocation (CELLINI; FERREIRA; ROTHSTEIN, 2010) 
the probability of having a birth, while the higher bound is close to a positive 3 p.p. From the our discussion in early sections, this seems counter intuitive, the income effect can be negative or, at most, have little effect.

Table 3 - Average treatment effects of Bolsa Familia UCT on the probability of having a birth, from 2012 to 2015 (dependent dummy variable)

\section{Basic inputs for bounds estimation}

Share of always assigned units $(\tau) \quad 0.071$

Increase in treatment take-up at the cutoff $\quad 0.505 \quad[0.494 ; 0.516]$

Had a birth on period 2012-2015

Estimate

$95 \% \mathrm{CI}$

\section{A. Dependent Variable Means}

UCT beneficiaries

0.25

UCT non-beneficiaries

0.176

\section{B. Sharp RD estimates}

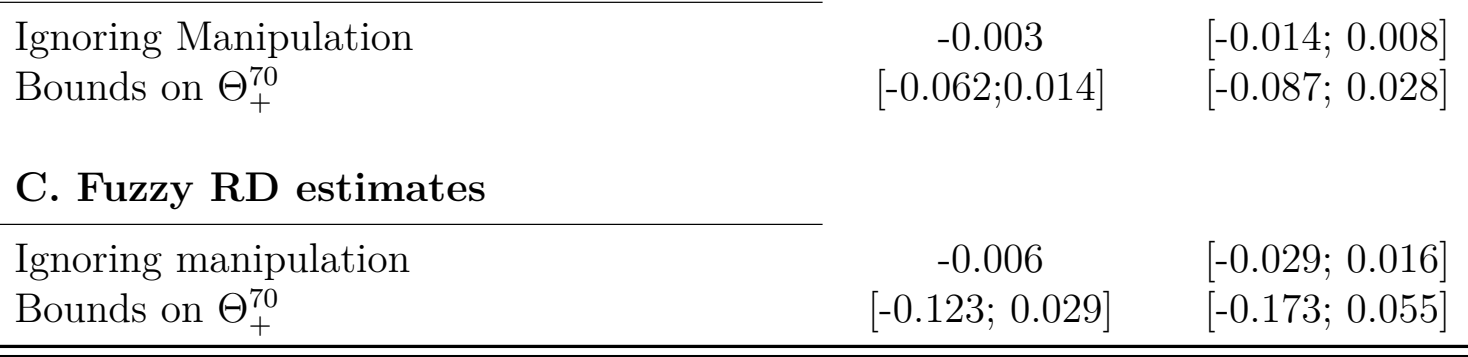

Notes: Notes: Total number of observations within our (rounded) bandwidth of $\mathrm{R} \$ 20$ around the cutoff: 168,686 beneficiaries women (aged 16-44) with at least one child. Confidence Intervals are based on 100 bootstrap samples. Bandwidth calculated by Calonico, Cattaneo \& Titiunik (2014) methodology. 
Figure 4 - Probability of having an additional child - 2012 to 2015

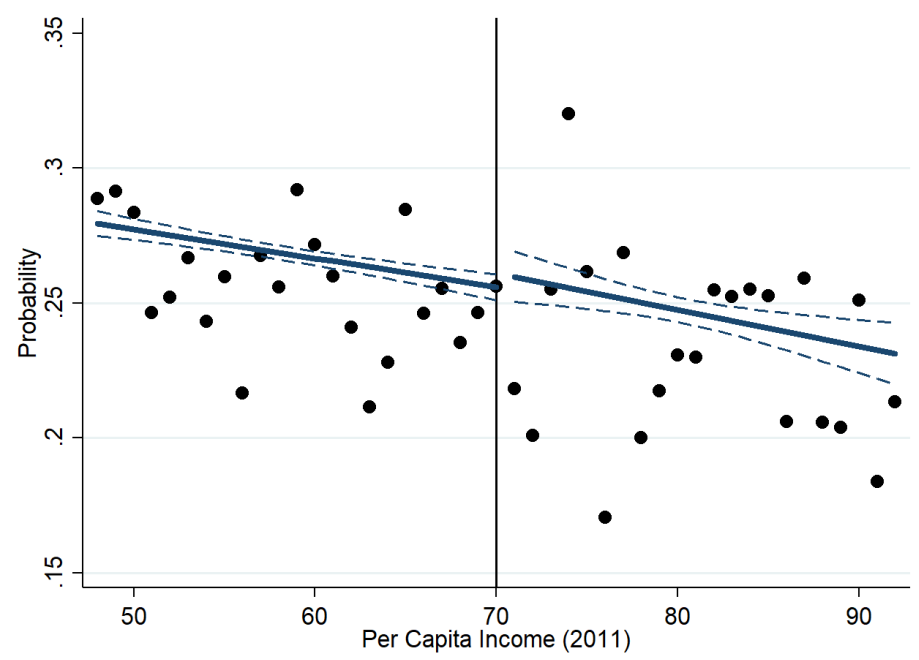

\subsection{Conditional Cash Transfer}

The CCT component of BF is given to all beneficiaries below the poverty cutoff, $\mathrm{R} \$ 140$. Since we do not have signs of manipulation around this cutoff, the parameter of interest is the standard RD estimate of equation 4.1 , with the $\mathrm{R} \$ 140$ cutoff instead of $\mathrm{R} \$ 70$. In an standard $\mathrm{RD}$, we can estimate $\Theta$ with the following regression, within a bandwidth around the cutoff:

$$
\text { Hadbirth }_{i}=\alpha_{0}+\alpha_{1} \text { municipality }+\Theta_{140} C C T_{i}+\theta_{1}\left(Y_{i}-c\right)+\theta_{2} \times C C T_{i} \times\left(Y_{i}-c\right)+\epsilon_{i}
$$

where Hadbirth is a dummy indicating at least one childbirth for woman $i$ during the period 2012 to 2015, CCT a dummy for CCT allocation in 2011, $c$ is the $2011 \mathrm{R} \$ 140$ cutoff, $Y_{i}$ the per-capita income of woman $i$ in 2011, municipality is a municipality fixed effect ${ }^{\dagger}$ and $\epsilon_{i}$ is the error term. As in the UCT case, our design is fuzzy, that is, the eligibility rule is not strictly applied. An IV strategy is applied, where the dummy variables $\mathbb{1}(Y \leq c)$ and $\mathbb{1}\left(Y_{i} \leq c\right) \times(Y-c)$ act as instruments for $C C T$ and $C C T \times\left(Y_{i}-c\right)$.

Figure 5 shows the CCT allocation around the cutoff. There's a clear discontinuity for CCT and, surprisingly, there are a non substantial amount of individuals earning UCT, despite being well above the extreme poverty cutoff. Although the UCT allocation have a discontinuity, it's not as large as the CCT. Table 4 shows the 1st stage regressions for our IVs. Panel A demonstrates that the discontinuity is strong in all of the 4 regressions for the CCT, and Panel B shows that the UCT's discontinuity is actually a non-linearity.

${ }^{\dagger}$ Units that change municipalities are not considered in the regression. More than $90 \%$ of the units around the cutoff remained in their 2011 municipality 


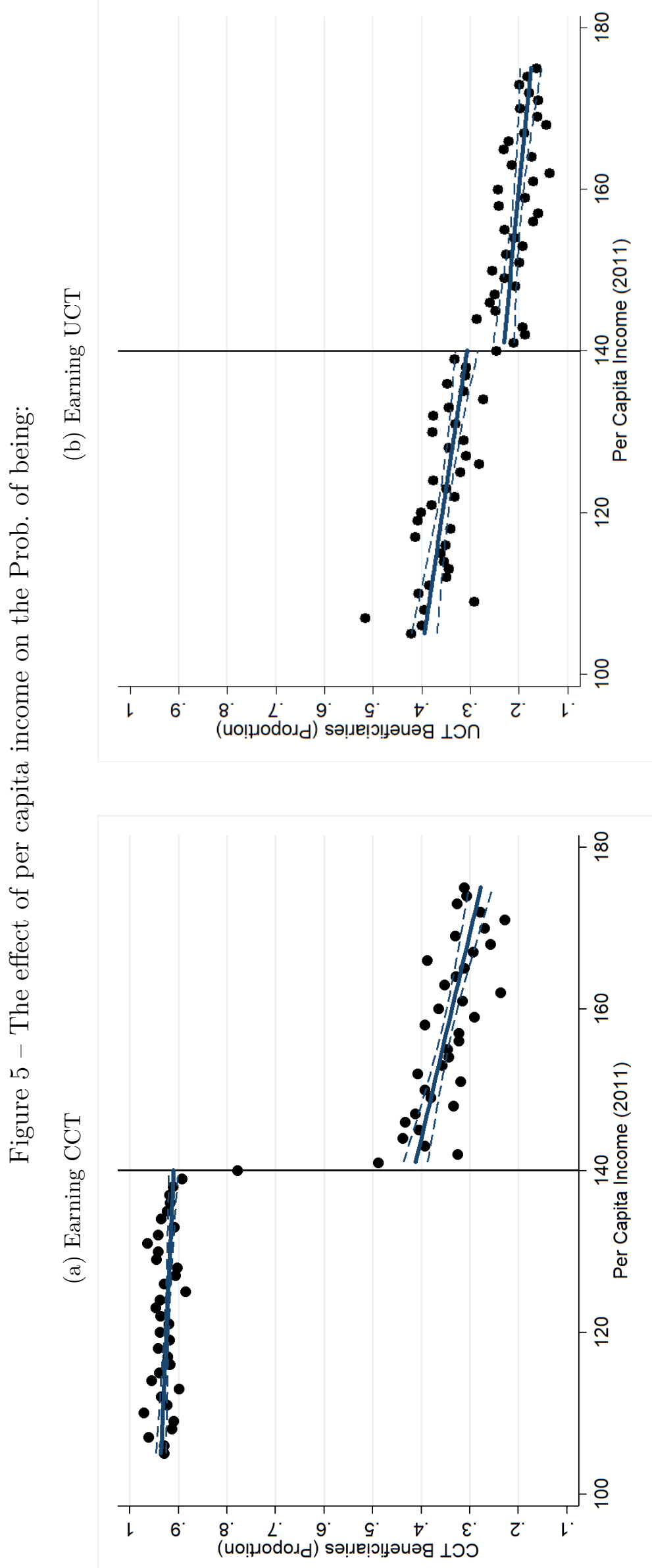


Table 4 - Effect of having a 2011 per capita income below the poverty cutoff ( $\mathrm{R} \$ 140)$ on the Prob. of earning CCT and UCT. Dependent variable: CCT/UCT beneficiary $(=1 / 0)$

\begin{tabular}{ccccc}
\hline \hline & \multicolumn{3}{c}{ Parametric Linear Regressions } \\
A. CCT & $(1)$ & $(2)$ & $(3)$ & $(4)$ \\
Below cutoff & $0.60^{* *}$ & $0.51^{* *}$ & $0.41^{* *}$ & $0.38^{* *}$ \\
& {$[6.26 \mathrm{e}-03]$} & {$[1.23 \mathrm{e}-02]$} & {$[1.69 \mathrm{e}-02]$} & {$[2.54 \mathrm{e}-02]$} \\
Controls & & & & \\
Income Linear Interaction & No & No & Yes & Yes \\
Income Quadratic Interaction & No & Yes & Yes & Yes \\
\hline Observations & 17,575 & 17,575 & No & Yes \\
R2 & 0.21 & 0.21 & 0.29 & 9,565 \\
B. UCT & & & & 0.29 \\
\hline Below cutoff & $0.15^{* *}$ & $0.07^{* *}$ & 0.04 & 0.04 \\
& $7.51 \mathrm{e}-03]$ & {$[1.42 \mathrm{e}-02]$} & {$[2.02 \mathrm{e}-02]$} & {$[2.92 \mathrm{e}-02]$} \\
Controls & & & & \\
No & No & Yes & Yes \\
Income Linear Interaction & No & Yes & Yes & Yes \\
\hline Ouadratic Interaction & No & No & No & Yes \\
\hline Observations & 17,575 & 17,575 & 9,565 & 9,565 \\
$R^{2}$ & 0.53 & 0.54 & 0.52 & 0.52 \\
\hline \hline
\end{tabular}

Notes: All regressions with municipality fixed effects. Observations within $\mathrm{R} \$ 43$ optimized bandwidth calculated by Calonico, Cattaneo \& Titiunik (2014) methodology. Heterocedastic robust-errors in Brackets. Controls: Dummies for each category of Race, Work, Education, Water, Wastewater, Garbage, Electricity, Income and Region categories of table A2. Additional Control dummies for age (5 years bin), Household (3 categories for number of rooms), disabilities, number of children and spouse. P-values: ${ }^{* *} \mathrm{p}<0.01,{ }^{*} \mathrm{p}<0.05$. Bandwidth calculated by Calonico, Cattaneo \& Titiunik (2014) methodology.

A good exercise to verify the RD validity is to compare observable variables above and below the cutoff. Table A5 shows the balancing using adjusted means. In general, we see that the differences are statistically insignificant or very small in magnitude, which strengthens the RD approach. And, as seen in subsection 3.5, we don't need to be concerned with manipulation problems.

Second stage results for equation 4.2 can be found in table 5 . and graphic visualization of the dependent variable around the cutoff is in 6. Visually there's a small but insignificant difference. Panel A shows the 'naive' sharp estimation, while Panel B shows the result for fuzzy estimates. First, we note that both sharp and fuzzy are very close to zero, and statistically not different from zero. Note that Using only up-to-date units for our fuzzy design changes the sign, which demonstrates that our suspicions of a downward bias caused by the attrition was correct, and that using all info, non-updated and updated, reduces the underestimation. However, both estimations shows no effect of CCT 
on fertility.

Figure 6 - Probability of having an additional child - 2012 to 2015

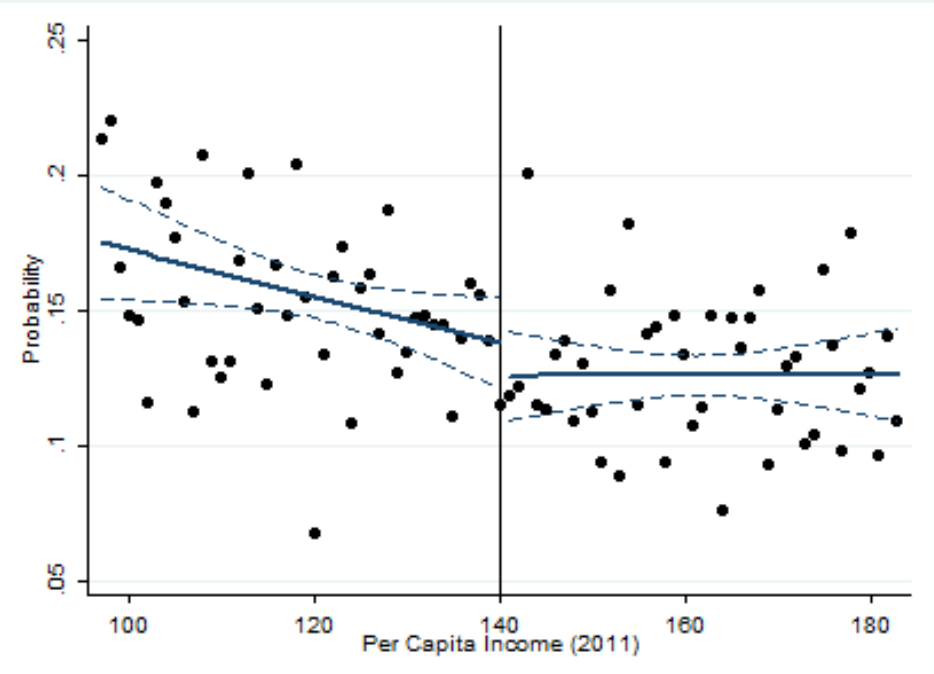

Table 5 - Average treatment effects of Bolsa Família CCT on the probability of having a childbirth, from 2012 to 2015. Dependent Variable: dummy variable indicating at least one childbirth for the 2012-2015 period

\begin{tabular}{|c|c|c|}
\hline & \multicolumn{2}{|c|}{ Had a birth in 2012-2015 } \\
\hline & Estimate & $95 \% \mathrm{CI}$ \\
\hline A.Sharp RD estimate & 0.01 & {$[-0.013 ; 0.032]$} \\
\hline \multicolumn{3}{|l|}{ B.Fuzzy RD estimates } \\
\hline$\Theta_{140}$ & 0.017 & {$[-0.026 ; 0.059]$} \\
\hline $\begin{array}{l}\Theta_{140} \text { (only up-to-date } \\
\text { units) }\end{array}$ & -0.059 & {$[-0.133 ; 0.014]$} \\
\hline
\end{tabular}

Notes: Total number of observations within our (rounded) bandwidth of $\mathrm{R} \$ 43$ around the cutoff for all units (updated and non-updated): 14,957 women with at least one child. Total number of observations for regressions with only upto-date units: 10,188. Mean dependent variable for CCT beneficiaries: 0.156. Mean dependent variable for non-CCT beneficiaries: 0.113. Confidence Intervals calculated with heterocedastic robust errors. Bandwidths calculated by Calonico, Cattaneo \& Titiunik (2014) methodology.

As seen in the first sections, BF beneficiaries have stronger incentives to keep their information updated. Although we're controlling for municipalities, which are the main factors that drives update behavior (e.g.: ease of access to city hall, resource allocation to registries team), one might imagine that the differences in attrition brought by the 
treatment bring unobservable variation that is affecting the results. Figure 7 and table 6 , shows the update pattern around the cutoff for 2015. On average, those below the cutoff have a 10 percentage points lower attrition rate. If we believe that this attrition might be driving results, we can apply the bounds strategy, as a robustness check.

Figure 7 - 2015 Update Pattern around the $\mathrm{R} \$ 140$ cutoff

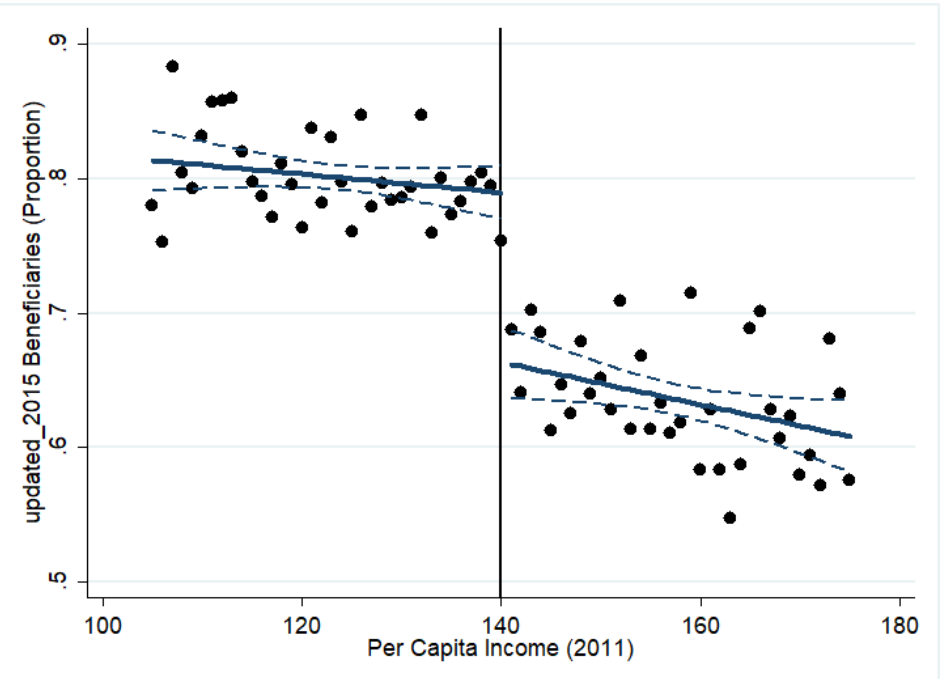

Table 6 - Effect of having a 2011 per capita income below the poverty cutoff $(\mathrm{R} \$ 70)$ on the Prob. of having an up-to-date Cadúnico registry in 2015. Dependent variable: Up-to-date 2015 Cadúnico Registry $(=1 / 0)$

\begin{tabular}{ccccc}
\hline \hline & \multicolumn{4}{c}{ Parametric Linear Regressions } \\
\hline & $(1)$ & $(2)$ & $(3)$ & $(4)$ \\
\hline Below cutoff & $0.18^{* *}$ & $0.13^{* *}$ & $0.12^{* *}$ & $0.11^{* *}$ \\
& {$[8.23 \mathrm{e}-03]$} & {$[1.55 \mathrm{e}-02]$} & {$[2.12 \mathrm{e}-02]$} & {$[3.14 \mathrm{e}-02]$} \\
Controls & & & & \\
Income Linear Interaction & No & No & Yes & Yes \\
Income Quadratic Interaction & No & No & Yes & Yes \\
\hline Observations & 15,989 & 15,989 & 8,881 & Yes \\
R2 & 0.21 & 0.22 & 0.26 & 0.26 \\
\hline \hline
\end{tabular}

Notes: Regressions with BF beneficiaries (2011 allocation) women within 16 to 44 years of age and with at least one child.Regressions with municipality fixed effects. Robust-errors clusterized by State in Brackets. Controls: Dummies for Race, Work, Education, Household (3 categories for number of rooms) Water, Wastewater, Garbage, Electricity, Income and Region categories of table A1. Dummies for age ( 5 years bin), disabilities, number of children and spouse. P-values:** $\mathrm{p}<0.05,{ }^{*} \mathrm{p}<0.01$. Bandwidth calculated by Calonico, Cattaneo \& Titiunik (2014) methodology. 
Consider then $U$ as being a dummy variable for attrition for the year 2015, assuming 1 when the individual have an up-to-date info in 2015, and 0 otherwise. For the interaction $U \times X$ is then possible to use the bounds of Gerard, Rokkanen \& Rothe (2016) to address the attrition problem. A jump at the cutoff for $U \times X$ might be seen as a manipulation problem, and thus the same strategy can be used to derive bounds on the treatment effects. Indeed, a McCrary test in Figure 11 shows a small jump in the $U \times X$ histogram. The parameter of our interest is the same as in equation 4.1, but potentially assigned units would be also units that on the absence of the treatment would not change their update pattern:

$$
\Theta_{+}^{140}=E\left(Y(1)-Y(0) \mid U \times X=c_{2}^{+}, D^{-}>D^{+}\right)
$$

where $c_{2}$ corresponds to the poverty cutoff. The results can be found in table 7. Panel A shows the same basic inputs as in table 3, with a slightly different interpretation. Always assigned are those that always keep their info update - and below the cutoff - in the presence of available treatment. The discontinuity is confirmed in Panel A, with a local linear regression estimation. Panel $\mathrm{B}$ and $\mathrm{C}$ shows that non parametric estimations yields the same results as in table 5 . The bounds estimation on this case are larger than in the UCT counterpart, although symmetrical. The larger upper and lower bound does not allow for meaningful results. The larger bounds are caused by the small difference in the basic inputs for bounds estimation (GERARD; ROKKANEN; ROTHE, 2016). Because we cannot control for municipality, a key variable for update behavior, the share of always assigned, that is, units that are updating due to treatment, increases substantially, which results in weaker inference. Similarly, the same can be argued for the differences in the dependent variable in panel A. Because CCT beneficiaries had more children, they have a small, but strong incentive to update the registry, which can increase the $\tau$ estimation.

\subsection{Heterogeneity Exercises}

In general, both BF's components do not seem to affect fertility decisions. However, some subsamples prone to have more children in the near future can have a different decision due to being a beneficiary (e.g.: younger woman or those with just one child). I conduct some heterogeneity exercises with certain distinctions: by region, by group age and by parity. For some groups, no evidence for manipulation was found; therefore no parametric estimation was made on these cases. By Region: I group Brazil's regions in three main groups: Center-west with North (the least populous regions); Southwest and South (the wealthiest regions), and the Northeast ${ }^{\ddagger}$. 2nd stage regressions can be found on A6 and A8 . Interestingly enough, only the NE region shows different results. On average,

\footnotetext{
$\ddagger$ The northeast is, proportionally, the region with higher population below the poverty lines and with higher incidence of Bolsa Família (SIMÕES; SOARES, 2012)
} 
Table 7 - Average treatment effects of Bolsa Familia CCT on the probabilty of having a childbirth, from 2012 to 2015

\begin{tabular}{|c|c|c|}
\hline \multicolumn{3}{|l|}{ Basic Inputs for bounds estimation } \\
\hline Share of always assigned units $(\tau)$ & 0.37 & {$[0.314 ; 0.424]$} \\
\hline \multirow[t]{3}{*}{ Increase in treatment take-up at the cutoff } & 0.418 & {$[0.385 ; 0.451]$} \\
\hline & \multicolumn{2}{|c|}{ Had a birth on period $2012-2015$} \\
\hline & Estimate & $95 \% \mathrm{CI}$ \\
\hline \multicolumn{3}{|l|}{ A. Dependent Variable Means } \\
\hline CCT beneficiaries & 0.156 & - \\
\hline non CCT beneficiaries & 0.113 & - \\
\hline \multicolumn{3}{|l|}{ B. Sharp RD estimates } \\
\hline Ignoring attrition (local linear regression) & -0.018 & {$[-0.047 ; 0.009]$} \\
\hline Bounds on $\Theta_{+}^{140}$ & {$[-0.198 ; 0.086]$} & {$[-0.221 ; 0.129]$} \\
\hline \multicolumn{3}{|l|}{ C. Fuzzy RD estimates } \\
\hline Ignoring attrition (local linear regression) & -0.046 & {$[-0.115 ; 0.022]$} \\
\hline Bounds on $\Theta_{+}^{140}$ & {$[-0.25 ; 0.227]$} & {$[-0.301 ; 0.342]$} \\
\hline
\end{tabular}

Notes: Total number of observations within our bandwidth of $\mathrm{R} \$ 43$ around the cutoff for Non Parametric Estimations: 11,133 women (aged 16-44) with at least one child. Confidence Intervals are based on 100 bootstrap samples.Bandwidths calculated by Calonico, Cattaneo \& Titiunik (2014) methodology.

an UCT reduces in 5 p.p. on the probability of having an additional birth. Again, this is counter intuitive: an income effect is actually decreasing fertility. By parity: Because parent's preferences on additional children in higher parities are similar Morgan \& King (2001), it would be interesting to look at different parities, like parity one or other lower groups. I analyze the first parity separately, while grouping the second and third parity together. (higher parities have small preferences to have additional children). The results, in tables A7 and A9 are similar to the main ones. By age group: I group together a younger section of the women (16-24 years), and I also analyze the older section (above 35 years) to verify effects. The results can be found on A7 and A9. Again, no different and significant results were found on both subsamples. On summary, when manipulation is not high, the heterogeneity results shows that both income and price effects are around zero, with asymmetrical bounds towards the negative side. 


\section{Conclusion}

More than a decade of its release, Bolsa Familia is a very, if not the most, important pillar of Brazil's welfare system. As other cash transfers, BF has made progress in education and health outcomes. It is not the primary objective of cash transfers programs to promote fertility. If fertility increases at large, the human capital accumulation per capita can decrease, even with incentives to education. This study reinforces past literature results using a more reliable data, with a new identification strategy. Using data from Cadúnico, the database used for assessing BF's eligibility, I take advantage of a discontinuity in the eligibility rule, implementing a regression discontinuity to verify the program's impact on fertility, being able to capture the UCT and the CCT parts of Bolsa Família, a unprecedented study for the BF program. A simple mean test will indicate that both UCT and CCT have positive effects on fertility, but that is not the case. The results demonstrates that bounds for "income" effect are around zero, with a large and negative lower bound. Interestingly, the income effect is actually negative for the Northeast region, Brazil's poorest region. Traditional RD analysis shows no price effect on fertility, for the CCT case. Although the RD analysis lacks external validity for those not close to the cutoff, this study may indicate that the BF program does not promote monetary incentives to fertility. In fact, increasing the money grant and relaxing the conditions can actually reduce fertility. 



\section{Bibliography}

BAIRD, S. et al. Relative effectiveness of conditional and unconditional cash transfers for schooling outcomes in developing countries: a systematic review. Campbell systematic reviews, The Campbell Collaboration, v. 9, n. 8, 2013. Citado na página 23.

BAIRD, S.; MCINTOSH, C.; ÖZLER, B. Cash or condition? evidence from a cash transfer experiment. The Quarterly Journal of Economics, Oxford University Press, p. qjr032, 2011. Citado na página 23.

BARRECA, A. I.; LINDO, J. M.; WADDELL, G. R. Heaping-induced bias in regression-discontinuity designs. Economic Inquiry, Wiley Online Library, v. 54, n. 1, p. 268-293, 2016. Citado na página 30.

BECKER, G. S.; LEWIS, H. G. Interaction between quantity and quality of children. In: Economics of the family: Marriage, children, and human capital. [S.1.]: University of Chicago Press, 1974. p. 81-90. Citado 2 vezes nas páginas 21 and 24.

BOR, J. Essays on the Economics of HIV/AIDS in Rural South Africa. Dissertação (ScD Dissertation) - Harvard School of Public Health, 2013. Citado 2 vezes nas páginas 24 and 25 .

CALONICO, S.; CATTANEO, M. D.; TITIUNIK, R. Robust nonparametric confidence intervals for regression-discontinuity designs. Econometrica, Wiley Online Library, v. 82, n. 6, p. 2295-2326, 2014. Citado 11 vezes nas páginas 38, 39, 42, 43, 44, 46, 60, 61, 62, 63 , and 64 .

CELLINI, S. R.; FERREIRA, F.; ROTHSTEIN, J. The value of school facility investments: Evidence from a dynamic regression discontinuity design. The Quarterly Journal of Economics, Oxford University Press, v. 125, n. 1, p. 215-261, 2010. Citado na página 38.

COCHRANE, S. H. Children as by-products, investment goods and consumer goods: a review of some micro-economic models of fertility. Population Studies, Taylor \& Francis, v. 29, n. 3, p. 373-390, 1975. Citado na página 21.

FISZBEIN, A.; SCHADY, N. R.; FERREIRA, F. H. Conditional cash transfers: reducing present and future poverty. [S.l.]: World Bank Publications, 2009. Citado 2 vezes nas páginas 21 and 23.

GARGANTA, S. et al. The effect of cash transfers on fertility: Evidence for argentina. CEDLAS (UNLP)-CONICET, 2014. Citado na página 24.

GERARD, F.; ROKKANEN, M.; ROTHE, C. Bounds on Treatment Effects in Regression Discontinuity Designs under Manipulation of the Running Variable, with an Application to Unemployment Insurance in Brazil. [S.1.], 2016. (Working Paper Series, 22892).

Disponível em: < http://www.nber.org/papers/w22892>. Citado 10 vezes nas páginas $9,11,21,30,32,33,35,36,38$, and 45 . 
LAGARDE, M.; HAINES, A.; PALMER, N. Conditional cash transfers for improving uptake of health interventions in low-and middle-income countries: a systematic review. Jama, American Medical Association, v. 298, n. 16, p. 1900-1910, 2007. Citado 2 vezes nas páginas 21 and 23.

LINDERT, K. et al. The nuts and bolts of Brazil's Bolsa Familia Program: implementing conditional cash transfers in a decentralized context. [S.l.], 2007. Citado 2 vezes nas páginas 25 and 27.

MCCRARY, J. Manipulation of the running variable in the regression discontinuity design: A density test. Journal of Econometrics, Elsevier, v. 142, n. 2, p. 698-714, 2008. Citado na página 32.

MDS, BRAZILIAN MINISTRY FOR AGRARIAN AND SOCIAL DEVELOPMENT. Bolsa Família Management Manual. Brasília/DF. Brazil, 2015. Citado 2 vezes nas páginas 26 and 27.

MORGAN, S. P.; KING, R. B. Why have children in the 21st century? biological predisposition, social coercion, rational choice. European Journal of Population/Revue européenne de Démographie, Springer, v. 17, n. 1, p. 3-20, 2001. Citado 2 vezes nas páginas 25 and 46.

PELLEGRINA, H. S. Evaluating the Impact of Bolsa Família Program on Dropout Rates and Performance. Dissertação (Master's Dissertation) — University of São Paulo, 2012. Citado na página 21.

ROCHA, R. C. B. da. Conditional cash-transfer programs and fertility: Evidence from bolsa-família. In: $31^{\circ}$ Meeting of the Brazilian Econometric Society. [S.l.: s.n.], 2010. Citado na página 25.

SCHULTZ, T. P. Demand for children in low income countries. Handbook of population and family economics, Elsevier, v. 1, p. 349-430, 1997. Citado 2 vezes nas páginas 21 and 24.

SCHULTZ, T. P. School subsidies for the poor: evaluating the mexican progresa poverty program. Journal of development Economics, Elsevier, v. 74, n. 1, p. 199-250, 2004. Citado na página 24.

SIGNORINI, B. A.; QUEIROZ, B. L. et al. The impact of bolsa familia program in the beneficiary fertility. Cedeplar/UFMG Working paper Series, Belo Horizonte/MG, Brazil, v. 439, 2011. Citado na página 25.

SIMÕES, P.; SOARES, R. B. Efeitos do programa bolsa família na fecundidade das beneficiárias. Revista Brasileira de Economia, SciELO Brasil, v. 66, n. 4, p. 445-468, 2012. Citado 2 vezes nas páginas 25 and 45.

SOARES, S. et al. Targeting and coverage of the Bolsa Familia Programme: Why knowing what you measure is important in choosing the numbers. Brasília/DF. Brazil, 2010. Citado na página 25.

STECKLOV, G. et al. Demographic externalities from poverty programs in developing countries: experimental evidence from latin america. American University: Washington DC Department of Economics Working Paper Series, 2006. Citado 4 vezes nas páginas 21, 23, 24, and 26. 
TODD, J. E.; WINTERS, P.; STECKLOV, G. Evaluating the impact of conditional cash transfer programs on fertility: the case of the red de protección social in nicaragua. Journal of Population Economics, Springer, v. 25, n. 1, p. 267-290, 2012. Citado 3 vezes nas páginas 24, 25, and 26.

TODD, P. E.; WOLPIN, K. I. Assessing the impact of a school subsidy program in mexico: Using a social experiment to validate a dynamic behavioral model of child schooling and fertility. The American economic review, American Economic Association, v. 96, n. 5, p. 1384-1417, 2006. Citado na página 24.

ZINN, S.; WÜRBACH, A. A statistical approach to address the problem of heaping in self-reported income data. Journal of Applied Statistics, Taylor \& Francis, v. 43, n. 4, p. 682-703, 2016. Citado na página 30. 

Appendix 



\section{APPENDIX A - Table Appendix}

Table A1 - Cadúnico's Federal programs

\begin{tabular}{|c|c|c|}
\hline Program & Description & Target \\
\hline $\mathrm{BPC}$ & 1 minimum wage per month & $\begin{array}{l}\text { Highly vulnerable wlderly or deficient } \\
\text { individuals }\end{array}$ \\
\hline Carteira do Idoso & Interstate transportation discounts & Elderly \\
\hline $\begin{array}{l}\text { Cestas Nutricionais para } \\
\text { Gestantes }\end{array}$ & Complementary feeding program & $\begin{array}{l}\text { Pregnant women in Alagoas State in food } \\
\text { insecurity situations }\end{array}$ \\
\hline PRONATEC & Free professional training & $\begin{array}{l}\text { Registered individuals between } 16 \text { and } 59 \\
\text { years old }\end{array}$ \\
\hline PETI & $\begin{array}{l}\text { Social activities and cash transfers } \\
\text { through BF }\end{array}$ & $\begin{array}{l}\text { Families below the poverty line and child } \\
\text { labor vulnerable }\end{array}$ \\
\hline Minha Casa, Minha Vida & Housing loans & All registered families \\
\hline $\begin{array}{l}\text { Tarifa Social de Energia } \\
\text { Eletrica }\end{array}$ & Electric Bills discounts & BPC's beneficiares families \\
\hline Programa de Cisternas & Subsidized cisterns & Any registered family \\
\hline Telefone Social & $\begin{array}{l}\text { Telecommunication services } \\
\text { discounts }\end{array}$ & Families below the poverty line \\
\hline $\begin{array}{l}\text { Fee isemption for } \\
\text { examinations }\end{array}$ & $\begin{array}{l}\text { Fee isemption for Civil service } \\
\text { entrance examination }\end{array}$ & Any registered individual \\
\hline Projovem & Conditional cash transfer program & $\begin{array}{l}\text { Any registered individual between } 15 \text { to } \\
29 \text { years of age with educational deficits }\end{array}$ \\
\hline
\end{tabular}

Table A2 - Summary Statistics (2011)

\begin{tabular}{|c|c|c|c|}
\hline Variables & Percentage/Mean & & Percentage/Mean \\
\hline Race: White & $29.9 \%$ & Wastewater: Sewer system & $46.2 \%$ \\
\hline Race: Black-Brazilian & $8.4 \%$ & Wastewater: Septic tank & $39.8 \%$ \\
\hline Race: Oriental & $0.7 \%$ & $\begin{array}{l}\text { Wastewater: Directly dis- } \\
\text { charged at water sources }\end{array}$ & $5.5 \%$ \\
\hline Race: Pardo-Brazilian & $60.1 \%$ & Wastewater: Others & $1.2 \%$ \\
\hline Race: Indigenous & $0.7 \%$ & Wastewater: Missing & $7.2 \%$ \\
\hline Race: Missing & $0.2 \%$ & Garbage: Collected & $77.0 \%$ \\
\hline $\begin{array}{l}\text { Work: Worked in the last } \\
\text { week }\end{array}$ & $29.1 \%$ & Garbage: Burned or Buried & $14.2 \%$ \\
\hline Work: Missing & $36.0 \%$ & $\begin{array}{l}\text { Garbage: Discharged at } \\
\text { open air }\end{array}$ & $1.8 \%$ \\
\hline Education: None or some & & & \\
\hline $\begin{array}{l}\text { Primary education }(<4 y r \text { of } \\
\text { education) }\end{array}$ & $12.6 \%$ & Garbage: Others & $7.0 \%$ \\
\hline $\begin{array}{l}\text { Education: Primary Incom- } \\
\text { plete }\end{array}$ & $32.9 \%$ & $\begin{array}{l}\text { Electricity: Electric supply } \\
\text { network }\end{array}$ & $89.8 \%$ \\
\hline $\begin{array}{l}\text { Education: Some High } \\
\text { School education }\end{array}$ & $25.0 \%$ & Electricity: Generators & $1.1 \%$ \\
\hline
\end{tabular}




\begin{tabular}{|c|c|c|c|}
\hline $\begin{array}{l}\text { Education: High school or } \\
\text { higher }\end{array}$ & $29.3 \%$ & Electricity: Candles & $1.2 \%$ \\
\hline Education: Missing & $0.3 \%$ & Electricity: Others & $4.6 \%$ \\
\hline Age & 28.0 & Electricity: Missing & $3.4 \%$ \\
\hline Have disabilities & $0.6 \%$ & Per Capita Income & $106.6(100.5)$ \\
\hline Live with spouse & $36.7 \%$ & Income: Receive pension & $12.7 \%$ \\
\hline Number of Children & $1.66(0.90)$ & Income: Donations & $6.5 \%$ \\
\hline Household: Urban & $82.1 \%$ & $\begin{array}{l}\text { Income: Unemployment } \\
\text { benefits }\end{array}$ & $0.6 \%$ \\
\hline $\begin{array}{l}\text { Household: Number of } \\
\text { rooms }\end{array}$ & $3.88(1.65)$ & $\begin{array}{l}\text { Income: other sources than } \\
\text { job related }\end{array}$ & $24.2 \%$ \\
\hline Household: piped water & $78.7 \%$ & Region: North & $14.2 \%$ \\
\hline $\begin{array}{l}\text { Household: piped water } \\
\text { (missing info) }\end{array}$ & $3.4 \%$ & Region: Northeast & $33.2 \%$ \\
\hline Household: Have bathroom & $78.7 \%$ & Region: Center-West & $8.3 \%$ \\
\hline $\begin{array}{l}\text { Household: Have bathroom } \\
\text { (missing info) }\end{array}$ & $3.4 \%$ & Region: Southeast & $33.9 \%$ \\
\hline Water: Supply network & $72.4 \%$ & Region: South & $10.3 \%$ \\
\hline Water: Artesian Aquifer & $18.6 \%$ & $\begin{array}{l}\text { BF beneficiaries (2011 allo- } \\
\text { cation) }\end{array}$ & $75.8 \%$ \\
\hline Water: Others & $5.6 \%$ & $\begin{array}{l}\text { UCT beneficiaries (2011 al- } \\
\text { location) }\end{array}$ & $75.6 \%$ \\
\hline Water: Missing & $3.4 \%$ & $\begin{array}{l}\text { CCT beneficiaries (2011 al- } \\
\text { location) }\end{array}$ & $58.6 \%$ \\
\hline Observations & & & 600,402 \\
\hline
\end{tabular}

Notes: This table presents summary statistics for key variables. Data comes from the merge of yearly data of cadúnico and Caixa Bolsa Familia's payment registries, from 2011 to 2015. I considered only 2011 entering families, in which the woman is considered head of the familiy (93\% of the families), within fertile age (16-44) and with at least one child. Standard deviation in parentheses, when applicable. 
Table A3 - Difference-in-Difference estimates for Update in Cadúnico Variables - Gamma coefficients

\begin{tabular}{|c|c|c|c|c|}
\hline \multirow[b]{2}{*}{ Variable } & \multicolumn{4}{|c|}{ Difference in years between updated and old info } \\
\hline & 1 Year & 2 Years & 3 Years & 4 Years \\
\hline Race: White & -0.001 & 0.001 & $0.005^{* *}$ & 0.003 \\
\hline Race: Black-Brazilian & $-0.001^{*}$ & $0.002^{*}$ & 0.001 & 0.001 \\
\hline Race: Oriental & 0.000 & 0.000 & 0.000 & 0.000 \\
\hline Race: Pardo-Brazilian & 0.001 & $-0.003^{*}$ & $-0.005^{* *}$ & -0.004 \\
\hline Race: Indigenous & $0.001^{* *}$ & 0.000 & 0.000 & 0.001 \\
\hline Work: Worked in the last week & $0.027 * *$ & $0.009^{*}$ & $0.057 * *$ & $0.068^{* *}$ \\
\hline Work: missing & $0.01^{* *}$ & $-0.035^{* *}$ & $-0.036^{* *}$ & $-0.123^{* *}$ \\
\hline $\begin{array}{l}\text { Education: none or some Primary } \\
\text { education (<4yr of education) }\end{array}$ & $-0.004^{* *}$ & -0.001 & 0.000 & -0.004 \\
\hline Education: Primary Incomplete & $0.002^{*}$ & $-0.004^{*}$ & $-0.005^{*}$ & $-0.01^{* *}$ \\
\hline Education: some High school & 0.001 & 0.001 & 0.000 & $0.01 *$ \\
\hline Education: High school or more & 0.000 & $0.004^{*}$ & 0.004 & 0.004 \\
\hline Age & -0.001 & 0.002 & 0.001 & -0.001 \\
\hline Have disabilities & $-0.002^{* *}$ & 0.001 & -0.001 & 0.001 \\
\hline Live with spouse & $0.022^{* *}$ & -0.003 & 0.004 & $-0.025^{* *}$ \\
\hline Number of Children & $0.036^{* *}$ & $-0.012^{* *}$ & $-0.025^{* *}$ & $-0.029 * *$ \\
\hline Household: Urban & 0.000 & 0.001 & 0.004 & 0.004 \\
\hline Household: number of rooms & $0.02^{* *}$ & 0.015 & 0.003 & 0.025 \\
\hline Household: piped water & $0.011^{* *}$ & $0.005^{*}$ & $0.008^{* *}$ & $0.016^{* *}$ \\
\hline Household: Have bathroom & $0.004^{* *}$ & 0.002 & -0.003 & 0.000 \\
\hline Water: Supply network & $0.006^{* *}$ & 0.003 & 0.001 & 0.007 \\
\hline Water: Artesian Aquifer & -0.001 & -0.001 & 0.000 & -0.006 \\
\hline Water: Others & $-0.003^{* *}$ & $-0.005^{* *}$ & $-0.005^{* *}$ & $-0.009^{* *}$ \\
\hline Wastewater: Sewer system & $0.003^{*}$ & -0.002 & -0.002 & -0.008 \\
\hline Wastewater: Septic Tank & 0.001 & 0.004 & 0.003 & 0.005 \\
\hline $\begin{array}{l}\text { Wastewater: Directly discharged at } \\
\text { water sources }\end{array}$ & $-0.004^{* *}$ & $-0.006^{* *}$ & $-0.006^{* *}$ & $-0.007^{* *}$ \\
\hline Wastewater: Others & -0.001 & $-0.002^{* *}$ & $-0.002^{*}$ & -0.001 \\
\hline Garbage: collected & 0.001 & 0.001 & -0.004 & $0.019^{* *}$ \\
\hline Garbage: burned/buried & $-0.002^{* *}$ & 0.000 & -0.001 & -0.004 \\
\hline Garbage: discharged at open air & $-0.002^{* *}$ & $-0.002^{* *}$ & $-0.004^{* *}$ & -0.001 \\
\hline Garbage: others & $0.003^{* *}$ & 0.001 & $0.008^{* *}$ & $-0.014^{* *}$ \\
\hline Electricity: Electric supply network & $0.006^{* *}$ & 0.002 & 0.002 & -0.001 \\
\hline Electricity: generators & $-0.001^{*}$ & $0.002^{*}$ & -0.001 & 0.000 \\
\hline Electricity: Candles & $-0.003^{* *}$ & $-0.002^{* *}$ & -0.001 & -0.001 \\
\hline Electricity: others & $-0.002^{* *}$ & $-0.005^{* *}$ & $-0.004^{* *}$ & $-0.007^{* *}$ \\
\hline Per Capita Income & $26.897^{* *}$ & $-9.753^{* *}$ & $-2.494^{*}$ & $-30.232^{* *}$ \\
\hline Income: Receive pension & $-0.007^{* *}$ & -0.005 & -0.002 & $-0.011^{*}$ \\
\hline Income: Donations & 0.001 & 0.000 & $-0.018^{* *}$ & $0.018^{* *}$ \\
\hline
\end{tabular}




\begin{tabular}{lcccc} 
Income: Unemployment benefits & $0.004^{* *}$ & $-0.004^{* *}$ & $-0.004^{*}$ & $-0.01^{* *}$ \\
$\begin{array}{l}\text { Income: other sources than job } \\
\text { related }\end{array}$ & 0.001 & $-0.013^{* *}$ & $-0.027^{* *}$ & $-0.088^{* *}$ \\
Region: North & 0.000 & 0.000 & 0.000 & -0.001 \\
Region: Northeast & $-0.002^{* *}$ & $-0.003^{* *}$ & -0.002 & $-0.007^{* *}$ \\
Region: Center-West & $0.001^{*}$ & 0.001 & 0.000 & $0.005^{* *}$ \\
Region: Southeast & $0.001^{*}$ & 0.001 & 0.002 & $0.004^{*}$ \\
Region:South & 0.000 & 0.000 & 0.000 & 0.000 \\
\hline \hline
\end{tabular}

Notes: Most regressions with a total of 1,957,544 observations. Robust-errors clusterized by NIS.

Column 1, 2, 3 and four corresponds to $\gamma_{1}, \gamma_{2}, \gamma_{3}$ and ${ }_{4}$ estimates of Equation ??, respectively.

Per-capita Income in January 2011 values. P-values: $*<0.05 ; * *<0.01$.

Table A4 - Difference-in-Difference estimates for Update in Cadúnico Variables - Beta coefficients

\begin{tabular}{|c|c|c|c|c|}
\hline \multirow[b]{2}{*}{ Variable } & \multicolumn{4}{|c|}{ Difference in years between updated and old info } \\
\hline & 1 Year & 2 Years & 3 Years & 4 Years \\
\hline Race: White & 0.000 & -0.001 & $-0.004^{*}$ & -0.003 \\
\hline Race: Black-Brazilian & 0.000 & $-0.002^{*}$ & -0.001 & 0.001 \\
\hline Race: Oriental & 0.000 & 0.000 & 0.000 & 0.000 \\
\hline Race: Pardo-Brazilian & 0.000 & $0.003^{*}$ & 0.003 & 0.002 \\
\hline Race: Indigenous & 0.000 & 0.000 & 0.000 & 0.000 \\
\hline Work: Worked in the last week & $0.033^{* *}$ & $0.049^{* *}$ & $0.08^{* *}$ & $0.11^{* *}$ \\
\hline Work: missing & $-0.152^{* *}$ & $-0.031^{* *}$ & $-0.096^{* *}$ & $-0.098^{* *}$ \\
\hline $\begin{array}{l}\text { Education: none or some Primary } \\
\text { education ( }<4 \mathrm{yr} \text { of education) }\end{array}$ & $-0.008^{* *}$ & $-0.005^{* *}$ & $-0.007^{* *}$ & $-0.005^{* *}$ \\
\hline Education: Primary Incomplete & $-0.009 * *$ & -0.002 & $-0.009 * *$ & $-0.007^{* *}$ \\
\hline Education: some High school & $0.005^{* *}$ & -0.001 & $-0.008^{* *}$ & $-0.015^{* *}$ \\
\hline Education: High school or more & $0.012^{* *}$ & $0.01 * *$ & $0.023^{* *}$ & $0.027^{* *}$ \\
\hline Age & $1.002^{* *}$ & -0.003 & -0.002 & $-0.004^{*}$ \\
\hline Have disabilities & $0.004^{* *}$ & 0.000 & $0.002^{*}$ & 0.000 \\
\hline Live with spouse & $-0.025^{* *}$ & -0.001 & $-0.017^{* *}$ & 0.006 \\
\hline Number of Children & $0.085^{* *}$ & $-0.008^{* *}$ & $-0.014^{* *}$ & $-0.038^{* *}$ \\
\hline Household: Urban & -0.001 & 0.000 & 0.001 & $0.006^{* *}$ \\
\hline Household: number of rooms & $0.087^{* *}$ & $0.071^{* *}$ & $0.16^{* *}$ & $0.208^{* *}$ \\
\hline Household: piped water & $0.012^{* *}$ & $0.013^{* *}$ & $0.02^{* *}$ & $0.013^{* *}$ \\
\hline Household: Have bathroom & $-0.003^{* *}$ & $0.007^{* *}$ & $0.016^{* *}$ & $0.01^{* *}$ \\
\hline Water: Supply network & 0.000 & $0.006^{* *}$ & $0.015^{* *}$ & $0.012^{* *}$ \\
\hline Water: Artesian Aquifer & $-0.004^{* *}$ & -0.002 & $-0.006^{* *}$ & -0.003 \\
\hline Water: Others & $-0.003^{* *}$ & 0.000 & $-0.004^{*}$ & -0.003 \\
\hline Wastewater: Sewer system & $-0.006^{* *}$ & $0.005^{*}$ & $0.01^{* *}$ & $0.023^{* *}$ \\
\hline Wastewater: Septic Tank & 0.001 & 0.000 & 0.002 & $-0.008^{*}$ \\
\hline $\begin{array}{l}\text { Wastewater: Directly discharged at } \\
\text { water sources }\end{array}$ & $-0.008^{* *}$ & 0.000 & -0.002 & -0.001 \\
\hline
\end{tabular}




\begin{tabular}{lcccc} 
Wastewater: Others & $-0.003^{* *}$ & 0.000 & 0.000 & -0.001 \\
Garbage: collected & $0.029^{* *}$ & $0.018^{* *}$ & $0.044^{* *}$ & $0.029^{* *}$ \\
Garbage: burned/buried & $-0.002^{*}$ & $-0.004^{* *}$ & $-0.007^{* *}$ & $-0.007^{* *}$ \\
Garbage: discharged at open air & $-0.002^{* *}$ & 0.000 & $0.002^{*}$ & 0.001 \\
Garbage: others & $-0.025^{* *}$ & $-0.014^{* *}$ & $-0.039^{* *}$ & $-0.023^{* *}$ \\
Electricity: Electric supply network & 0.001 & $0.01^{* *}$ & $0.017^{* *}$ & $0.014^{* *}$ \\
Electricity: generators & 0.000 & $-0.002^{* *}$ & 0.000 & -0.001 \\
Electricity: Candles & $-0.001^{* *}$ & -0.001 & $-0.002^{*}$ & 0.000 \\
Electricity: others & $-0.006^{* *}$ & $-0.004^{* *}$ & $-0.01^{* *}$ & $-0.007^{* *}$ \\
Per Capita Income & $-24.372^{* *}$ & $22.266^{* *}$ & $30.678^{* *}$ & $54.419^{* *}$ \\
Income: Receive pension & $0.013^{* *}$ & -0.004 & $-0.032^{* *}$ & $-0.038^{* *}$ \\
Income: Donations & $0.011^{* *}$ & 0.001 & $0.016^{* *}$ & $-0.007^{*}$ \\
Income: Unemployment benefits & $-0.004^{* *}$ & $0.007^{* *}$ & $0.009^{* *}$ & $0.015^{* *}$ \\
Income: other sources than job & $-0.055^{* *}$ & $-0.028^{* *}$ & $-0.062^{* *}$ & $-0.052^{* *}$ \\
related & 0.000 & 0.000 & 0.000 & 0.000 \\
Region: North & $0.002^{* *}$ & 0.001 & $-0.003^{* *}$ & $-0.003^{*}$ \\
Region: Northeast & 0.000 & 0.000 & 0.001 & 0.000 \\
Region: Center-West & $-0.002^{* *}$ & 0.000 & 0.002 & $0.003^{*}$ \\
Region: Southeast & $0.001^{*}$ & 0.000 & 0.000 & 0.000 \\
Region:South & $0.95 * 5$ & & & \\
\hline \hline
\end{tabular}

Notes: Most regressions with a total of 1,957,544 observations. Robust-errors clusterized by NIS. Column 1, 2, 3 and four corresponds to $\beta_{1}, \beta_{2}, \beta_{3}$ and $\beta_{4}$ estimates of Equation ??, respectively. Per-capita Income in January 2011 values. P-values: $*<0.05 ;{ }^{*}<0.01$.

Table A5 - Covariates Comparison - Above and Below the poverty cutoff

\begin{tabular}{|c|c|c|c|}
\hline Variables & $\begin{array}{c}\text { Raw Mean } \\
\text { below the } \\
\text { cutoff }\end{array}$ & $\begin{array}{c}\text { Raw Mean } \\
\text { above the } \\
\text { cutoff }\end{array}$ & Difference \\
\hline Race: White & 0.377 & 0.360 & 0.017 \\
\hline Race: Black-Brazilian & 0.094 & 0.096 & -0.003 \\
\hline Race: Oriental & 0.007 & 0.007 & $0.001^{* *}$ \\
\hline Race: Pardo-Brazilian & 0.516 & 0.529 & -0.013 \\
\hline Race: Indigenous & 0.003 & 0.003 & $-0.001^{* *}$ \\
\hline Race: Missing & 0.002 & 0.005 & $-0.003^{* *}$ \\
\hline Work: Worked in the last week & 0.372 & 0.336 & 0.037 \\
\hline Work: Missing & 0.278 & 0.355 & -0.078 \\
\hline $\begin{array}{l}\text { Education: None or some Primary education } \\
\text { ( }<4 \text { yr of education) }\end{array}$ & 0.091 & 0.107 & -0.017 \\
\hline Education: Primary Incomplete & 0.320 & 0.349 & -0.029 \\
\hline Education: Some High School education & 0.256 & 0.256 & -0.001 \\
\hline Education: High school or higher & 0.329 & 0.285 & 0.044 \\
\hline Education: Missing & 0.004 & 0.002 & $0.002^{* *}$ \\
\hline Age & 30.31 & 29.97 & 0.34 \\
\hline
\end{tabular}




\begin{tabular}{|c|c|c|c|}
\hline Have disabilities & 0.009 & 0.007 & $0.003^{* *}$ \\
\hline Live with spouse & 0.599 & 0.521 & 0.079 \\
\hline Number of Children & 2.040 & 2.158 & -0.119 \\
\hline Household: Urban & 0.902 & 0.886 & 0.017 \\
\hline Household: Number of rooms & 4.299 & 4.163 & 0.136 \\
\hline Household: piped water & 0.894 & 0.869 & 0.025 \\
\hline Household: piped water (missing info) & 0.024 & 0.022 & $0.002^{*}$ \\
\hline Household: Have bathroom & 0.954 & 0.949 & 0.005 \\
\hline Household: Have bathroom (missing info) & 0.024 & 0.022 & $0.002^{*}$ \\
\hline Water: Supply network & 0.824 & 0.801 & 0.023 \\
\hline Water: Artesian Aquifer & 0.128 & 0.141 & -0.014 \\
\hline Water: Others & 0.025 & 0.035 & $-0.01^{*}$ \\
\hline Water: Missing & 0.024 & 0.022 & $0.002^{*}$ \\
\hline Wastewater: Sewer system & 0.596 & 0.564 & 0.032 \\
\hline Wastewater: Septic tank & 0.335 & 0.362 & -0.027 \\
\hline Wastewater: Directly discharged at water sources & 0.028 & 0.031 & $-0.003^{*}$ \\
\hline Wastewater: Others & 0.005 & 0.007 & $-0.002^{* *}$ \\
\hline Wastewater: Missing & 0.036 & 0.037 & $-0.001^{*}$ \\
\hline Garbage: Collected & 0.852 & 0.825 & 0.027 \\
\hline Garbage: Burned or Buried & 0.058 & 0.070 & -0.012 \\
\hline Garbage: Discharged at open air & 0.006 & 0.007 & $-0.001^{* *}$ \\
\hline Garbage: Others & 0.060 & 0.075 & -0.016 \\
\hline Electricity: Electric supply network & 0.946 & 0.933 & 0.014 \\
\hline Electricity: Generators & 0.001 & 0.002 & $-0.001^{* *}$ \\
\hline Electricity: Candles & 0.002 & 0.003 & $-0.002^{* *}$ \\
\hline Electricity: Others & 0.027 & 0.040 & $-0.013^{*}$ \\
\hline Electricity: Missing & 0.024 & 0.022 & $0.002^{*}$ \\
\hline Income: Receive pension & 0.166 & 0.221 & -0.055 \\
\hline Income: Donations & 0.086 & 0.133 & -0.048 \\
\hline Income: Unemployment benefits & 0.013 & 0.008 & $0.005^{*}$ \\
\hline Income: other sources than job related & 0.153 & 0.255 & -0.103 \\
\hline Region: North & 0.072 & 0.087 & -0.016 \\
\hline Region: Northeast & 0.193 & 0.225 & -0.032 \\
\hline Region: Center-West & 0.106 & 0.084 & 0.022 \\
\hline Region: Southeast & 0.476 & 0.458 & 0.019 \\
\hline Region: South & 0.153 & 0.146 & 0.008 \\
\hline CCT beneficiaries (2011 allocation) & 0.654 & 0.346 & 0.309 \\
\hline
\end{tabular}

Notes:Most regressions with a total of 17,575 observations (least: 10,257). Observations within the $\mathrm{R} \$ 43$ bandwidth calculated by Calonico, Cattaneo \& Titiunik (2014) methodology. Difference in means adjusted by per capita income (2011 R $\$$ values), with hetorecedasticity-robut errors. P-values: $*<0.05 ; * *<0.01$. 


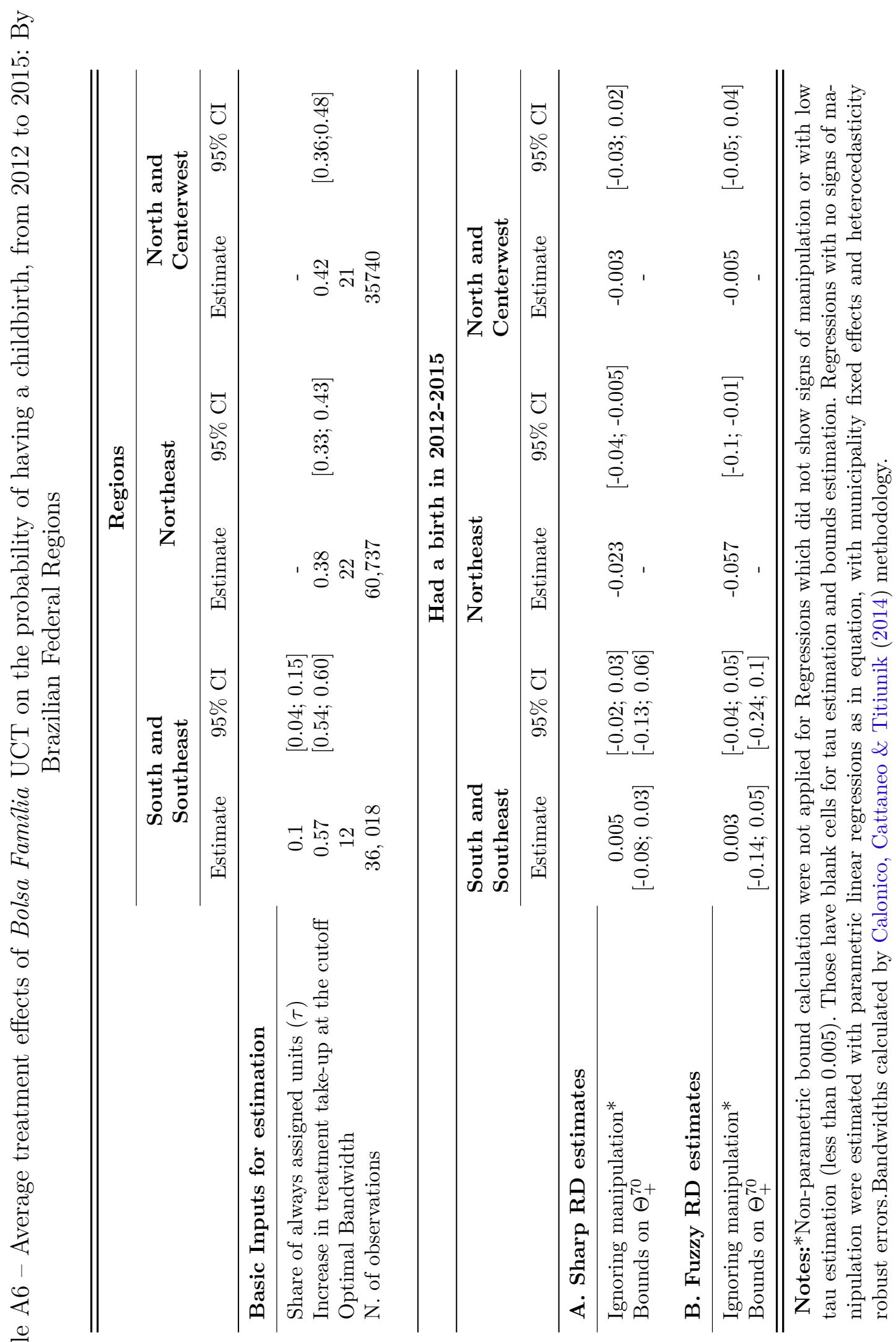




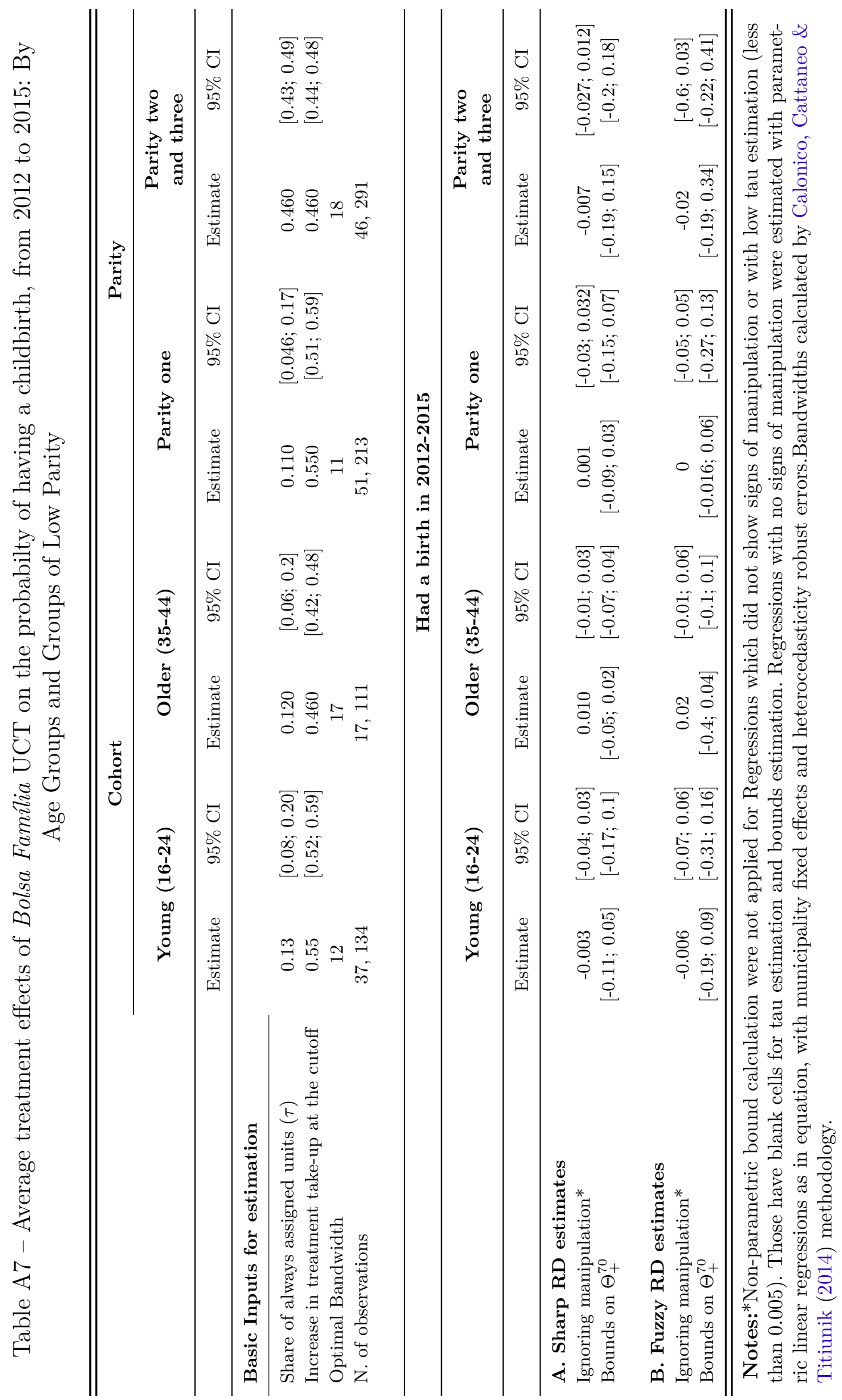




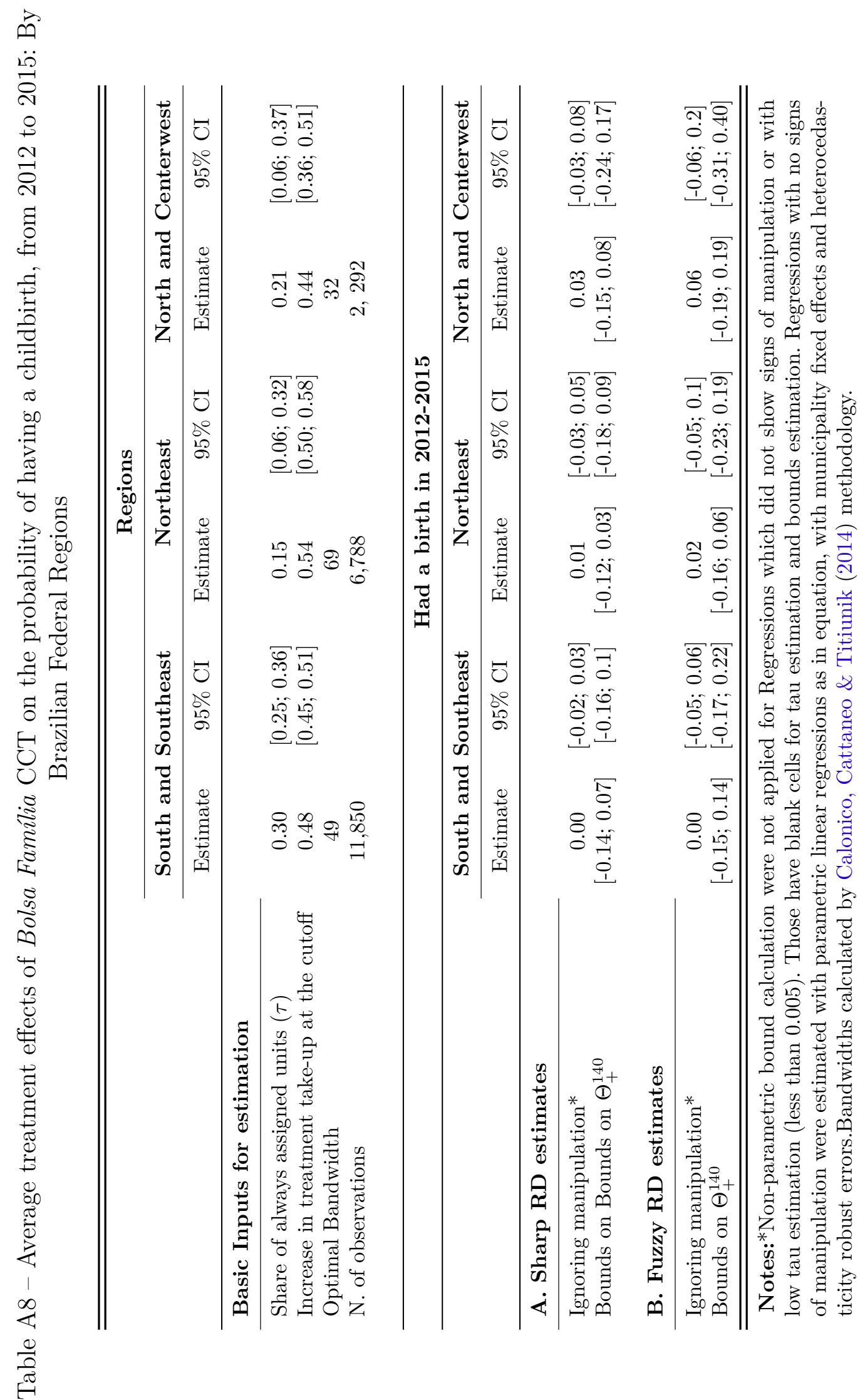




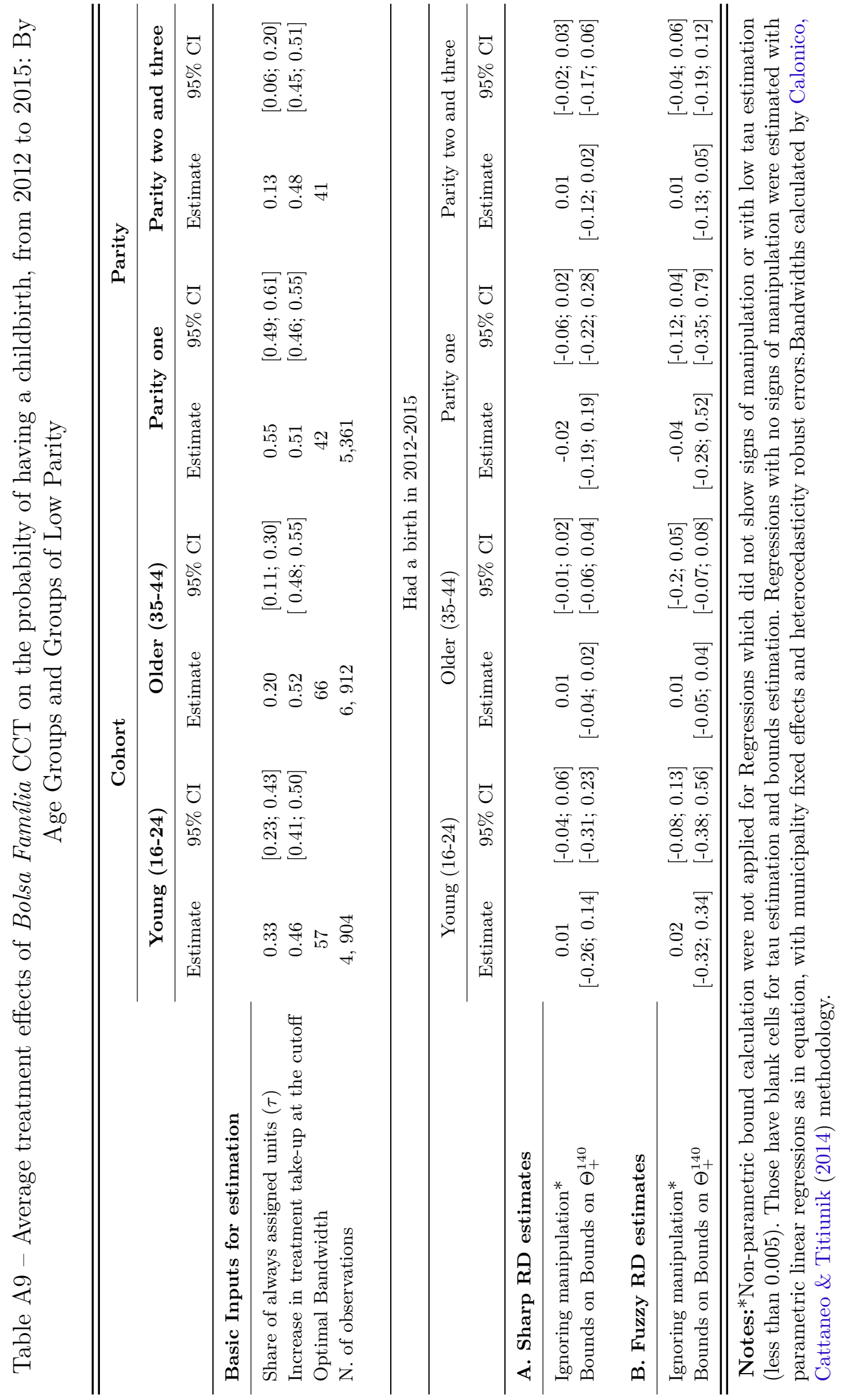




\section{APPENDIX B - Figures Appendix}

Figure 8 - McCrary Test for UCT cutoff: extreme poverty line*

(a) General

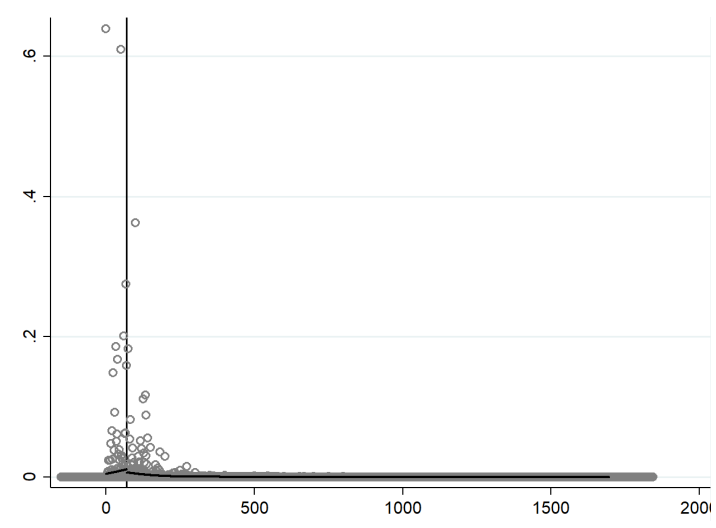

(b) Magnified

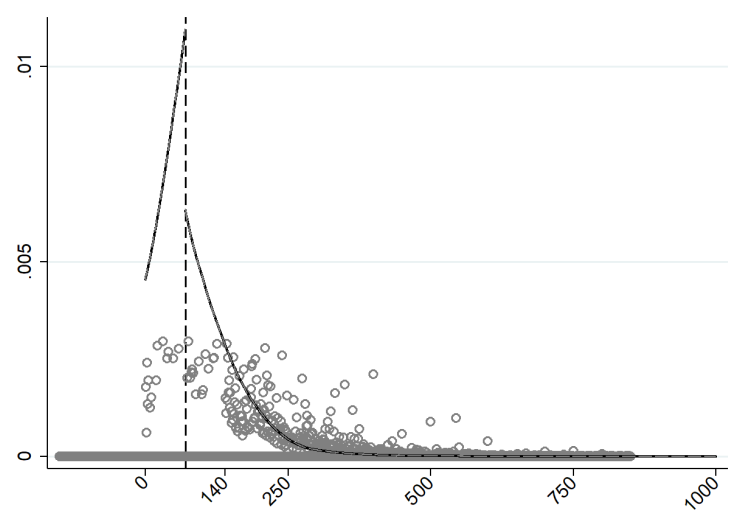

Figure 9 - McCrary Test for CCT cutoff: poverty line, non-heaped*

(a) General

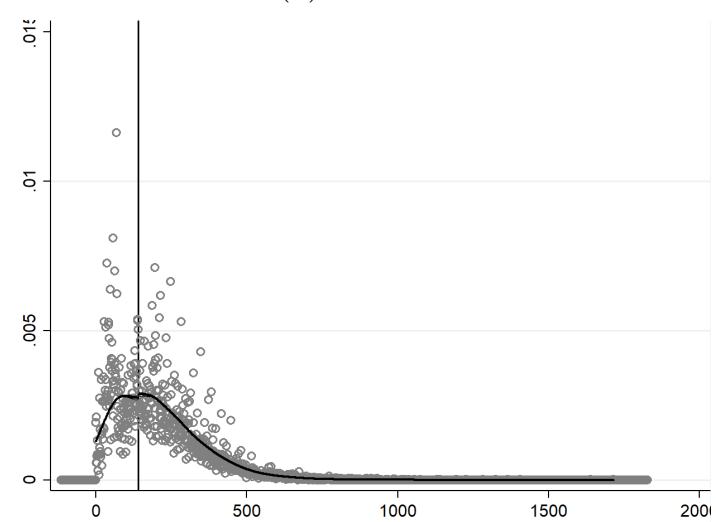

(b) Magnified

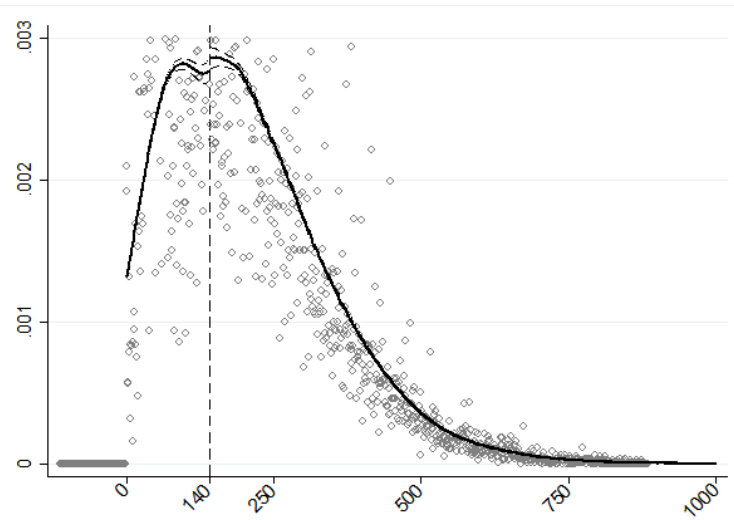

*Mccrary standard test. Unit of observation: registered women in 2011 cadúnico with age ranging from 16 to 44 years old, with at least one child. N. of obs.: 74,532 (140 cutoff); 36,232 (70 cutoff). P-values: 140 cutoff: 0.3 . 70 cutoff: $<0.01$.

*Mccrary standard test. Unit of observation: registered women in 2011 cadúnico with age ranging from 16 to 44 years old, with at least one child. Only using non-heaped units (total family income report with last digit 1-9). N. of obs.: 74,532 (140 cutoff); 36,232 (70 cutoff). P-values: 140 cutoff: 0.3 .70 cutoff: $<0.01$. 
Figure 10 - McCrary Test for CCT cutoff: poverty line, non-heaped*

(a) General

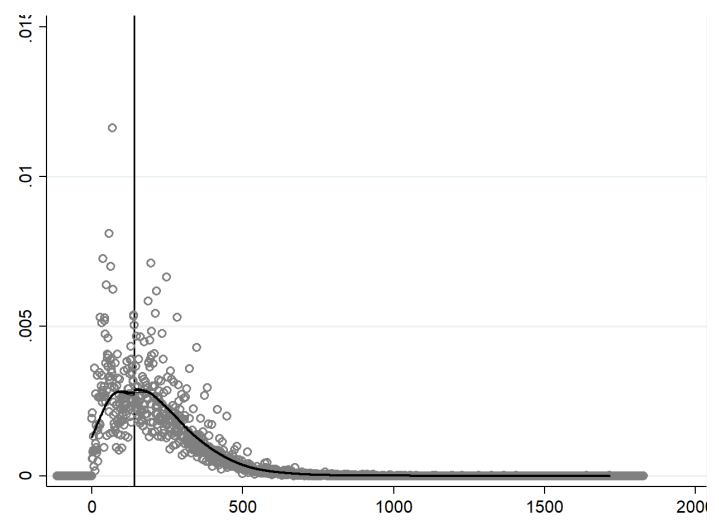

(b) Magnified

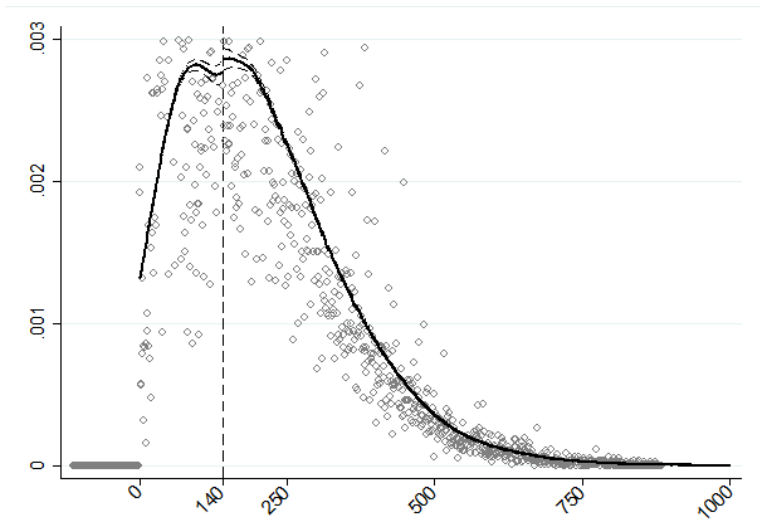

Figure 11 - McCrary Test for update pattern around the R\$140 cutoff*

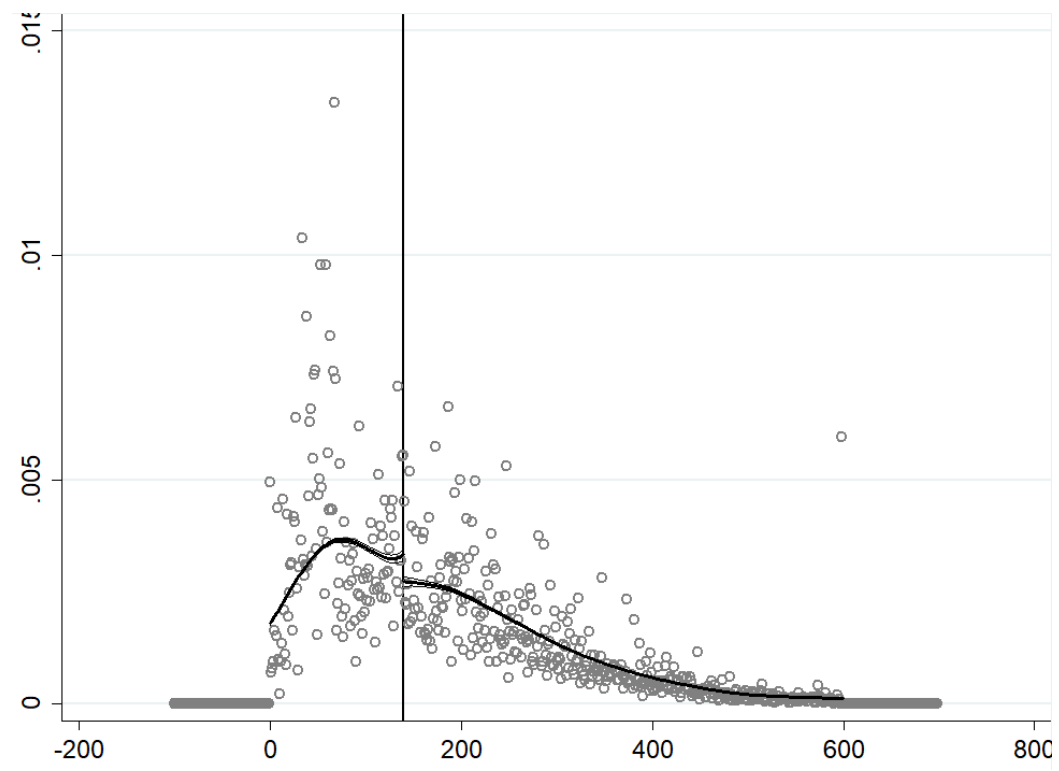

*Mccrary standard test. Unit of observation: registered women in 2011 cadúnico with age ranging from 16 to 44 years old, with at least one child. Only using non-heaped units (total family income report with last digit 1-9). N. of obs.: 43,908. P-value: $<0.01$. 
